\title{
Power, Jurisdiction, and Criminal Investigation
}

Reggio Emilia was the seat of a diocese, which stretched northwest towards the Po, and south into the Apennines, where it was bounded by a series of mountain passes. The western boundary was partially marked by the river Enza and the eastern was largely marked by the river Secchia. In the central part of this long and narrow territory, Reggio lay on the via Emilia, which bisected the diocese. The history of the city of Reggio has been the subject of some important studies. In the early twentieth century, Natale Grimaldi made a careful study of Reggio Emilia during the rule of Barnabò Visconti. ${ }^{1}$ More recently, Andrea Gamberini's rigorous examination of political identity at Reggio during the Visconti age has revealed political tensions and internal conflict. ${ }^{2}$

In the thirteenth century, Reggio Emilia had been a prosperous town of about 17,000 inhabitants, ${ }^{3}$ with perhaps another 25,000 in the 2,500 kilometers of territory under its jurisdiction. ${ }^{4}$ The largely agricultural economy rested on the produce of the surrounding lands, which included grains, rice, grapes, mulberries, and other products. ${ }^{5}$ During the period of communal rule, the city was home to a law school, ${ }^{6}$ and even a mint. But the fourteenth century Reggio Emilia faced a difficult series of economic, political, and especially demographic changes, as the population was reduced to approximately 3,000

1 Natale Grimaldi, La signoria di Barnabò Visconti e di Regina della Scala in Reggio (1371-1385): Contributo alla storia delle signorie italiane (Reggio Emilia: Cooperativa Lavoranti Tipografi, 1921).

2 Andrea Gamberini, La città assediata: poteri e identità politiche a Reggio in età viscontea (Rome: Viella, 2003). On medieval Reggio Emilia, see also the essays collected in Gino Badini and Andrea Gamberini, eds., Medioevo Reggiano: studi in ricordo di Odoardo Rombaldi (Milan: FrancoAngeli, 2007).

3 Andrea Gamberini, "Una città e la sua coscienza comunitaria," in Oltre le città: Assetti territoriali e culture aristocratiche nella Lombardia del tardo Medioevo (Rome: Viella, 2007), 85.

4 Grimaldi, La signoria di Barnabò Visconti, 127.

5 Girolamo Tiraboschi, Dizionario topografico-storico degli Stati estensi, vol. 2 (Modena, 1725), 244 .

6 Rashdall called this school, together with that at Modena, "the most formidable of Bologna's younger rivals." Hastings Rashdall, The Universities of Europe in the Middle Ages, eds. F.M. Powicke and A.B. Eden, vol. 2, new edition (Oxford: Oxford University Press, 1951), 6-7.

(C) Joanna Carraway Vitiello, 2016 | DOI 10.1163/9789004311350_003

This is an open access title distributed under the terms of the Creative Commons Attribution-

Noncommercial-NonDerivative 3.0 Unported (CC-BY-NC-ND 3.0) License, which permits any noncommercial use, and distribution, provided no alterations are made and the original author(s) and source are credited. 
inhabitants in the city, with a possible 4,500 to 5,000 in the district. ${ }^{7}$ In part this was due to the plague, ${ }^{8}$ which arrived at Reggio Emilia in March of 1348 , an epidemic "horrible and enormous" as the chronicler of Reggio Emilia remembered: “... concerning this disease I cannot describe the horrors, and cruelties, and darkness." Public health efforts failed, ${ }^{10}$ and recurrent epidemics were accompanied by famine, as in 1373-4, when "a measure of flour cost by the Cremonese measure five imperial pounds, and beans cost four. So cruel a famine, from which many perished of hunger, was never heard of or seen before."11

The political landscape was also shifting. By the mid-fourteenth century, the continual ascendance of the Visconti family of Milan was reshaping northern Italian politics. After the death in 1354 of their uncle, the Archbishop Giovanni Visconti, the brothers Galeazzo and Barnabò Visconti shared control of the Milanese territory. Galeazzo controlled the western half, including Genoa, keeping his residence after 1359 at Pavia, and Barnabò held the eastern half, including Parma, Piacenza, and for a brief time, Bologna, with his administration settled in Milan. ${ }^{12}$ Soon after the death of Giovanni, Genoa regained independence, while the papacy retook control of Bologna. The desire to regain control of these cities shaped the policies of their reigns. ${ }^{13}$

Reggio Emilia's geographic position, strategically convenient for eastward expansion to Bologna, made it an attractive acquisition to both the Visconti and the Este of Ferrara. Since 1359 Reggio had been under the control of Feltrino Gonzaga, but his unpopular rule was already falling to pieces

$7 \quad$ Gamberini, La città assediata, 91.

8 On the Black Death at Reggio, see Corrado Corradini, "Davanti alla morte in tempo di peste a Reggio Emilia (1348): aspetti religiosi" in Medioevo reggiano: studi in ricordo di Odoardo Rombaldi, eds. Gino Badini and Andrea Gamberini (Milan: FrancoAngeli, 2007).

9 Sagacius et Petrus de Gazata, Chronicon Regiense, in RIS 18, col. 66: "Isto anno usque ad Festum omnium sanctorum ... fuit morbus horribilis, et tremendus. Qui conversabatur cum infirmo, moriebatur..." Gazata, Chronicon Regiense, col. 66: "De hoc morbo non possem scribere horribilitates, et crudelitates, et obscuritates, que fuerunt."

10 For example, in 1371, the Podestà, Julianus Spinolle, and the captain of the city, Balzarius de Pusterla, ordered the public crier to make a proclamation forbidding anyone from lands infected with plague to come to Reggio Emilia. ASRe, Comune, Registri dei decreti, reg. 1372-1375, September 25, 1373 .

11 Gazata, Chronicon Regiense, col. 83. "Valuit starium frumenti ad mensuram Cremonae libras quinque imperialium et faba libras quatuor imperialium. Numquam audita, nec visa fuit tam crudelis caristia, unde multi fame perierunt."

12 D.M. Bueno de Mesquita, Giangaleazzo Visconti: A Study in the Political Career of an Italian Despot (Cambridge: Cambridge University Press, 1941), 6-7.

13 Bueno de Mesquita, Giangaleazzo Visconti, 7. 
during the 1360's as the feudal families of the Reggiano largely disregarded his authority. ${ }^{14}$ Ultimately the Este of Ferrara hired the notorious mercenary leader, Lutz von Landau, in their bid to take the city, and the mercenaries carried out a destructive rampage that lasted for twenty days. ${ }^{15}$ Niccolò d'Este, the author of that disaster, was still remembered with anger years later by the chronicler of Reggio, who wrote on the occasion of his death, "He was always a weak man, and a cruel lord, and he was very bad for the city of Reggio: for it was he who brought [our city] to destruction and despoliation."16

When Feltrino saw that the Este soldiers had taken the city, he offered to sell it to Barnabò Visconti for the price of 50,000 florins in an effort to save himself. ${ }^{17}$ The treaty was completed on May 17, 1371, and Barnabò paid the soldiers of Landau's company 25,000 florins to leave. ${ }^{18}$ Barnabò himself employed the company of the famous English mercenary, John Hawkwood, together with his illegitimate son, Ambrogio Visconti, and he quickly took possession of the city. ${ }^{19}$ Weakened by a long term of inept Gonzaga government, devastated by

14 Grimaldi, La signoria di Barnabò Visconti, 17-21. Feltrino had little local support. In theory, his rule was under the protection of the papacy, but in reality he was isolated. The Gonzaga abandoned him too-when initially the Este believed they would take possession of Reggio from Feltrino and informed the Gonzaga of Mantua, they responded with congratulations. Francesco Cognasso, "Istituzioni comunali e signorili di Milano sotto Visconti," in Il ducato visconteo e la repubblica ambrosiana (1392-1450), Storia di Milano 6, eds. Giuseppe Martini et al. (Milan: Fondazione Treccani, 1955), 465-466.

15 The loyalties of the nobility of the Reggiano were divided. The Este commanded the loyalty of some important noble families like the Fogliani, Manfredi, Roberti, and Reteglia, as well as a large part of the city's inhabitants. The Visconti claimed loyalty from other families of the contado, among them the Pico della Mirandola, the Pio di Carpi and the Canossa. Grimaldi, La signoria di Barnabò Visconti, 21-24; Cognasso, "Istituzioni comunali e signorili di Milano sotto Visconti," 465. The siege and the damage inflicted by the soldiers on the inhabitants of Reggio Emilia is described in detail in the Chronicon Estense, cum additamentis uque ad annum 1478, ed. Muratori, RIS, vol. 15 (1729), col. 495-497.

16 Gazata, Chronicon Regiense, col. 96: "MCcClXXXviI die XXIII. Octobris moritur Dominus Nicolaus de Este Marchio Ferrariae, \& Dominus Ferrariae ac Mutinae. Hic fuit homo semper infirmus, et crudelis Dominus, et malus pro Civitate Rhegii; nam fuit ille, qui eam posuit in exterminio, et spoliatione."

17 Grimaldi, La signoria di Barnabò Visconti, 5 .

18 Cognasso, "Istituzioni comunali e signorili di Milano sotto Visconti," 466.

19 Grimaldi, La signoria di Barnabò Visconti, 21. But his own mercenary forces brought further discord to Reggio and especially towns like Guastalla. William Caferro, John Hawkwood: An English Mercenary in Fourteenth-Century Italy (Baltimore: Johns Hopkins University Press, 2006), 141-142. 
the brutality of Landau's soldiers, the inhabitants of Reggio Emilia found themselves situated precariously on the border as animosity between the Este and the Visconti grew. The Este leader recognized his defeat, but, as one Bolognese chronicler reported, he "remained cheated, and was a worse neighbor than before." ${ }^{20}$ The conquest brought a new political reality to Reggio.

Barnabò's wife, the formidable Regina della Scala, administered Reggio Emilia from soon after its acquisition until her death in $1384 .{ }^{21}$ In June of 1372 , Barnabò wrote to the Podestà, the captain, and other officials, instructing them to write to Regina, not to him, for all their concerns, ${ }^{22}$ and during the first twelve years of Visconti control in Reggio, it was Regina who made appointments, decided appeals, and administered affairs. Together with her husband, Regina visited Reggio Emilia in 1372 and was, according to the author of the Chronicon Regiense, deeply moved by the devastation of the city:

Lord Barnabò with his wife came to Reggio at the twentieth hour, and rode around the walls, which along with the gates he greatly admired because of their oak; but when he rode through the city, he was deeply

20 Matthaeus de Griffonibus, Memoriale Historicum de rebus bononiensium Matthaei de Griffonibus, RIS II, vol. 18 part 2 (1902), 69: 28.

21 On the technical nature of her power, see F.E. Comani, "Sui domini di Regina della Scala e dei suoi figli: indagini critiche," Archivio storico lombardo 29 (1902): 211-248. Reggio was not her only property: during the course of her 40-year marriage to Barnabò, she held many lands from him. At the time she acquired Reggio Emilia, for example, she had already controlled lands near Besciano for almost sixteen years. The letter of concession of these lands, dated Feb. 12, 1366, is printed in Caterina Santoro, La politica finanziaria dei Visconti: Documenti. Vol. 1, Settembre 1329-Agosto 1385 (Milan, 1976). At Reggio, the first surviving letter addressed to her from officials of the city is dated April 21, 1372; see Grimaldi, La signoria di Barnabò Visconti, 86. For a full discussion of her properties, see Comani, "Sui domini di Regina della Scala," 230-239. Lands of the bishopric of Luni were also sold to her, as was Reggio, though the record of the sale has not survived. F.E. Comani, "Usi cancellereschi viscontei," Archivo storico lombardo 27 (1900): 153. In addition, she administered fiefs in Lunigiana, Parmigiano, and the Riviera de Salò. Erskine D. Muir, A History of Milan under the Visconti (London: Methuen, 1924), 202.

ASRe, Comune, Provvigioni dei deputati sulle entrate, reg. ${ }^{3} 37^{-}-75$, fol. 46 , quoted in Grimaldi, La signoria di Barnabò Visconti, 87: “... and thus you should do everything she orders you, and ... you should give notice to all the vicars and officials of our district of Reggio, so that they serve this in the same way." "Volumus quod de omnibus necessariis et omnibus que occurent in terris cure vestre commissis: de cetero aliquid nobis non scribatis. Sed omnia que scribenda habebitis scribatis Illustri Domine consorti nostre: et sic faciatis omnia que ipsa vobis mandabit: et de predictis noticiam faciatis omnibus vicariis et officialibus districtus nostri egii ut illud idem servent.") 
saddened by the devastation of the homes, and even more so was his wife. The citizens visited him in the evening, whom he kindly received; but he wondered at the paucity of men, which he would scarcely believe, had he not made inquiries. He gave them great encouragement, promising that they should be strong in mind, since he would quickly restore their city, and he said that they might send to Parma after him, and anything they should wish from him, he would concede with a happy heart. ${ }^{23}$

Contemporary accounts agree that the city was in full demographic crisis, one claiming that "when Lord Barnabò secured [Reggio], there were not in this city twenty men of the city ..." ${ }^{24}$ The scarcity of doctors of law in the region meant that few civil cases could be tried, ${ }^{25}$ and the city also lacked other professionals, like physicians. Very soon after the acquisition of Reggio, the Podestà asked for permission to salary a doctor to keep him in the city. It was not unusual for Italian cities to provide public salaries for physicians, who rendered public services like crime reporting or the provision of public health measures. But the Podestà wanted to salary the physician so that he would stay, fearing that if

23 Gazata, Chronicon Regiense, col. 77: “[1371] Die Xxı. Octobris Dominus Barnabòs cum eius uxore venit Rhegium hora vigesima, et equitavit circum muros, quos cum portis eius plurimum est admiratus propter robur eius, sed cum per Civitatem equitavit, valde condoluit de domorum vastatione, et magis eius uxor. Cives illum vespere visitarunt, quos benigne suscepit; sed admiratus est paucitatem hominum, quod vix credere poterat, nisi de paucitate perquisivisset. Ipse hortatus est eos plurimum, promittens, ut essent forti animo, quia in brevi eam restauraret, dixitque, quod Parmam post eum mitterent, et quidquid ab ipso vellent, eis gratanti animo concederet."

24 "Et quando [dominus Bernabovis] ipsam fulcivit, non erant in ipsa civitate viginti homines ipsius civitatis." Memoriale potestatum Regiensium, RIs, vol. 8 (1726), col. 1176, quoted in Gamberini, 90 n. 41. Andrea Gamberini has found further reference to Reggio's poor state even in a commentary on the Divine Comedy by Benvenuto da Imola, who wrote of the example of "the noble city of Reggio in Lombardy, whose citizens are thus dispersed through Italy..." See Gamberini, La città assediata, 90-91 n. 42: "Today we have as a clear example before our eyes the noble city of Reggio in Lombardy, whose citizens are thus dispersed through Italy; just as the Jews are continuously spread out throughout the whole world, so also has this miserable spectacle come to pass for these wanderers." ("Sicut est hodie evidens exemplum habemus prae oculis nobilem civitatem Reginam Lombardia, cuius cives ita sunt dispersi per Italiam, sicut Judaei per universum et continuo consumuntur, ita ut miserabile spectaculum fit pertranseuntibus.") 
he left, "no other medical doctor would then be in this your city, and indeed it should not be hoped at the present time that another will return."26

In the years immediately after the city fell to Visconti rule, some halting steps towards recovery were attempted. Regina della Scala took measures to ensure basic provisions, ordering a "certain quantity of flour" to be sent to Reggio, which she wished to have "sold and distributed" amongst the citizens and inhabitants of the city of Reggio. ${ }^{27}$ And while in 1372, the Podestà feared that no physician would take up practice in Reggio, within the next four years, the presence of at least three surgeons is attested in surviving records, ${ }^{28}$ at least one of whom was also receiving a public salary by 1373. But the slow and painful nature of the recovery is still clear from the pleas of the Podestà for different and more lucrative appointments, ${ }^{29}$ and perhaps there was no recovery at all: in 1371, when it met to confirm Barnabò as the signore of Reggio Emilia, the council numbered 600 men, which must have included most of the adult men still living in the city. In later years, the number declined to 350 men present in the general council in 1382 and only 247 in 1394, though it is difficult to say whether this was because the population was in decline or whether people lost interest in serving on a council whose power was eroding. ${ }^{30}$ Recovery was not helped by new sources of unrest: almost immediately, Barnabò began a

26 ASRe, Comune, Registri dei decreti, reg. 1371-72, September 10, 1371: "Item dignetur ob salute civium vestrorum et forensium habitantium et in civitate vestre prefacta providere quod magister Paulus physicus qui stetit octo annis elapsis salarium a dicto Domino Feltrino in civitate predicta non recedat de prefacta civitate cum nullus alius medicus physicus sit in dictam vostram civitatem nec etiam expetiet de presenti aliquis reversurus. Responsio Domini: contentamus quod sibi provideatur per commune Regii per modum quod dictus medicus ibi stet."

27 ASRe, Proviggioni, May 11, 1372, vol. 2, 6v.

28 The three surgeons are Magister Antonius de Cassinariis, Nicoloxius Spander de Alamania, and Gabrielis de Medicis de Reggio ASRe, Comune, Registri dei decreti, reg. 1372-1375, November 19, 1373, 57v (Antonius de Cassinariis); ASRe, Giudiziario, Libri delle denunzie, June 11, 1374, vol. 11, fol. 118r (Nicoloxius Spander de Alamania, and Gabrielis de Medicis de Reggio).

29 Grimaldi, La signoria di Barnabò Visconti, 93.

3o Gamberini, La città assediata, 92 and 92 n. 48. David Chambers suggested that in early fifteenth century Mantua, the slack attendance at mandatory council meetings may have been likely due "not so much to tyranny [of the Gonzaga] as to public apathy and contentment with the regime." David S. Chambers, "The Gonzaga Signoria, Communal Institutions and 'the Honour of the City': Mixed ideas in Quattrocento Mantua." in Communes and Despots in Medieval and Renaissance Italy, eds. John E. Law and Bernadette Paton (Farnham: Ashgate, 2010), 111. 
bloody war to acquire Modena (1371-1375). ${ }^{31}$ His interest in Bologna meant continuous conflict with the papacy, for which Reggio, and perhaps especially its clergy, would pay a price. The papacy struck back, suspending the offices of clergy loyal to the Visconti, and Barnabò in turn placed new restrictions on all the clergy in his lands. All of this ultimately encouraged a brief revolt in Reggio, which once again found itself a battleground, ${ }^{32}$ and tensions remained high throughout 1373 and into 1374, when a tentative peace was reached. ${ }^{33}$ Civic religion was not a cohesive influence at Reggio, and the church itself was subsumed inside local politics. ${ }^{34}$ In addition to the obvious destabilizing effects of this violence, the longer-term consequences included the disorder caused by the omnipresent mercenary companies and all the issues that accompanied housing them. ${ }^{35}$

During the 1370 and early 1380 , Reggio remained under the control of Barnabò and Regina. After Regina died in 1384, her properties reverted to Barnabò, but in 1385, in a bloodless coup that sent shockwaves through northern Italy and even north of the Alps, his nephew Giangaleazzo Visconti seized control of his uncle's territories and united the Visconti state under one ruler. ${ }^{36}$ Barnabò died later that year in prison, and Reggio, together with the rest of

31 Grimaldi, La signoria di Barnabò Visconti, 4-5.

32 Caferro, John Hawkwood, 154-155 and 154 n. 50.

33 Bueno de Mesquita, Giangaleazzo Visconti, 8-9.

34 The rural nobility formed alliances not just with ecclesiastical instutitons in their own territories but also with those in the city, hence the association of the Roberti with the monastery of Santa Chiara, the da Sesso with the monastary of San Tomaso, and the Cannosa with San Raffaele. Gamberini, “Una città e la sua coscienza comunitaria," 92.

35 The same register of decrees from 1371 includes a request to Barnabò to aid those inhabitants of Reggio who were forced from their homes to accommodate these hired soldiers, or stipendiarii, and foreign officials. Emphasis is placed on the circumstances of inhabitants of Reggio who had fled under the Gonzaga because of the bad state of the city (propter mallum [sic] statum civitatis) and their concerns with their property, ASRe, Comune, Registri dei decreti, reg. 1371-72, September 10, 1371, 11r; and also on the concerns of citizens and inhabitants whose homes had been confiscated or damaged by the stipendiarii. ASRe, Comune, Registri dei decreti, reg. 1371-72, September 10, 1371, fols. 11r-12r.

36 Perhaps fearing for his own autonomy, Giangaleazzo rode with his usual bodyguard to Milan, with, as the chronicler of Reggio described, "many arms hidden under his clothes," (Gazata, Chronicon Regiense, col. 92: "Dominus Comes Virtutum ... simulavit, se velle adimplere votum ad Sanctam Mariam super Comum, et venit Mediolanum cum multis armatis sub vestibus...") claiming that he wished to pay his respects to his uncle but was afraid to enter the gates of the city. Barnabò met his nephew outside Milan without protection, and was immediately taken captive and imprisoned. 
his territories, passed into the control of Giangaleazzo Visconti for the next seventeen years.

Giangaleazzo keenly sought to avoid the stigma of tyranny and to seek legitimacy through a ducal title granted by the Emperor. ${ }^{37}$ His conception of the state was strong and unified, ${ }^{38}$ and he instituted important reforms in the subject cities. In Reggio Emilia, he made new appointments to the most powerful offices-Podestà, Capitano, and Referendario—and he centralized financial admistration, over which he exerted a close control. His interest in maintaining order in the countryside was apparent, as he instituted a new office to control the dangerous rural territory and fortified the castles and military outposts. But many of his reforms had antecedents in Barnabò's rule, and, as Gamberini observed, it is difficult to describe the new age at Reggio under Giangaleazzo as a strong break with the past. ${ }^{39}$

Yet his consolidation of the formerly divided Visconti dominions drove other northern Italian powers to form new coalitions against the Visconti. The dominating conflict was with Florence, with which Giangaleazzo was at war from 1390. A powerful recurrence of plague in 1399-1400 prevented Giangaleazzo from raising money through taxation to support his ongoing campaigns, and trade was compromised as roads and mountain passes became increasingly unsafe. His willingness to offer pardons to outlaws willing to return to his dominion, and to pardon convicted criminals in return for three months of military service, may be symptoms of the new economic and demographic problems he faced.$^{40}$ The death of Giangaleazzo in 1402 from illness gave new fuel to the internal disorders and external enemies Giangaleazzo had worked to suppress, and "Visconti ascendancy would now be tested almost to destruction." ${ }^{41}$ Giangaleazzo's young son Giovanni Maria inherited the ducal title, and under the duchess Caterina, a ruling council was established. But the ensuing disorder left the door open for leading families to make efforts to seize power, and for the loss of territories. ${ }^{42}$

37 See Jane Black, "Giangaleazzo Visconti and the Ducal Title," in Communes and Despots in Medieval and Renaissance Italy, eds. John E. Law and Bernadette Paton, 119-130.

38 Gamberini, La città assediata, 267.

39 Gamberini, La città assediata, 266-7.

40 Bueno de Mesquita, Giangaleazzo Visconti, 293-296.

41 Jane Black, Absolutism in Renaissance Milan (Oxford: Oxford University Press, 2009), 72.

42 On this transition and especially on the fate of the ducal title during this period, see Black, Absolutism in Renaissance Milan, 72-78. 
At Reggio, power would come to the hands of Ottobuono Terzi, a condottiero who, at the time of Giangaleazzo's death in 1402, commanded a large force involved in the Visconti war with Florence. Accounts of Ottobuono have left an historical impression of a bloody and ruthless tyrant, but this black legend has recently been greatly moderated. ${ }^{43}$ Unlike other condottieri, who left Visconti service for Florence, Ottobuono maintained close ties to the Visconti even after Giangaleazzo's death, and by July of 1403 , he was commissario ducale in Reggio, Parma, Piacenza, and several other cities. ${ }^{44}$ Slowly-and more or less legitimately, through agreements with Milan - he built a signorial regime. In 1404, he was proclaimed dominus in Reggio in the general council, as he was also at Parma and then at Piacenza. ${ }^{45}$ In short order he revised the statutes, most importantly, removing references to Visconti decrees. ${ }^{46}$ His rule shows that the "collapse of the Visconti edifice does not signify the collapse of the form of the 'state' in the Padane region." 47 But his efforts to expand eastward, especially to Modena, were interpreted as acts of open aggression by the Este of Ferrara, who, together with the Malatesta, the Gonzaga, and with wavering support from Giovanni Maria Visconti, ultimately united in their consideration of Ottobuono as a public enemy. ${ }^{48}$ Ultimately, almost five years to the day after seizing power at Parma, Ottobuono was killed on May 9, 1409 at Rubiera by Niccolò d'Este. ${ }^{49}$ With his death, the city was once again brought under the control of an ascendant power, as it was absorbed into the territories of the Este.

43 Andrea Gamberini, "Un condottiero alla conquista dello Stato. Ottobuono Terzi, conte di Reggio e signore di Parma e Piacenza," in Medioevo reggiano: studi in ricordo di Odoardo Rombaldi (Milan: Franco Angeli 2007), 282-305.

44 Andrea Gamberini, "Principi in guerra: Ottobuono Terzi e i suoi nemici," in Oltre la città: Assetti territoriali e culture aristocratiche nella Lombardia del tardo medioevo (Rome: Viella, 2009), 141.

45 Gamberini, "Un condottiero alla conquista dello Stato," 295.

46 ASRe, Comune, Statuti del 1404; Gamberini, "Un condottiero alla conquista dello Stato," 296.

47 Gamberini, "Un condottiero alla conquista dello Stato," 296-7.

48 See Gamberini's analysis in "Un condottiero all conquista dello Stato," 291-292.

49 Historiae Parmensis fragmenta ab anno мccсI usque ad annum McccLV. RIs, vol. 12 (1728), col. 752: "1409. A die 9. di Maggio Otto Terzo fu morto a Rubera da Nicolao da Este, essendo andato per trattare di pace con quello, il quale era suo compadre. Et il prefato giorno Nicolao Estense entrato in Parma, hebbe di quella il dominio." 


\section{The Signore and the Law at Reggio Emilia}

The authority held by the Visconti in their territories was theoretically complete. The grant of the imperial vicariate - which had cost Giovanni, Matteo and Barnabò Visconti 150,000 florins in 1355 - carried with it immense power. Barnabò, upon receiving the title, understood himself as "pope and emperor as well as signore in all my lands. Not the emperor, not even God, can do anything in my territories unless I wish it." ${ }^{50}$ The right of the Visconti to wield plenitudo potestatis was supported by such jurists as Baldus degli Ubaldi: effectively there were no restraints on the power of the signore to act contrary to the law, and fourteenth-century legal theory of the plenitudo potestatis tended to reflect the actions and practices of the signori. ${ }^{51}$ In general, the Visconti, by virtue of their plenitudo potestatis, were not bound to uphold statute law and were able to supersede these laws at will. ${ }^{2}$

In practice, however, the degree to which signorial authority ultimately displaced communal authority remains a difficult question. According to Grimaldi, the Visconti, "... by rendering inactive and superfluous the institutions of communal government, and gathering into their own hands absolute power, destroyed the substance and in large part also the form of republican government, substituting in the commune the political and administrative forms of the Principality" 53 This may perhaps be an overstatement in that much of the external structure of communal government appears to survive into the signorial age. However, certainly the force of those institutions did change: the city councils, for example, still met but they could be convened or

Black, Absolutism in Renaissance Milan, 52. The grant of the vicariate was for life to the brothers and to their heirs, but only as long as they remained loyal to the empire, and it was suspended in 1372 after a rift developed between the Visconti and the new emperor Wencenslaus. Yet Barnabò and Galeazzo continued to use the title and claim the privledges associated with it, and only Giangaleazzo would attempt to gain a limited renewal of the grant, first in 1380, and then finally a full grant in 1396. Jane Black, "The Visconti in the Fourteenth Century and the Origins of their Plenitudo Potestatis," in Reti Medievali Rivista 5 (2004): 7-8. On Giangaleazzo's 1395/1396 investiture, see Black, "Giangaleazzo Visconti and the Ducal Title," 119-130.

$5^{1} \quad$ Black, Absolutism in Renaissance Milan, 35.

$5^{2}$ Black, Absolutism in Renaissance Milan, 48.

53 Grimaldi, La signoria di Barnabò Visconti, 85: “... i Visconti nella seconda metà del XIV secolo, rendendo inattivi e superflui gli organi propri del governo comunale, accentuando nelle loro mani il potere assoluto, distruggono la sostanza e in gran parte anche la forma del governo repubblicano, sostituendo al comune le forme politiche e amministrative del Principato." 
dismissed by an order of the signore, and assemblies could not be held without a general or special license. ${ }^{54}$

Perhaps most importantly for the purposes of this study, Barnabò revolutionized the hierarchy of laws in his domain. Traditionally during the communal period, municipal statutes were the first level of authority. In cases where the statutes were inadequate, recourse could be made to the ius commune. ${ }^{55}$ The local statutes, therefore, embodied a great deal of power, and the processes by which they could be changed or altered were controlled, in the communes, by municipal councils. But under Barnabò, this changed: now the first law to be consulted was that of the signorial decree, then the municipal law, and lastly the ius commune. ${ }^{56}$ This was in keeping with other signorial regimes, which, as Vallerani observed, “... presented themselves as 'freed' from the law, but maintained an ambiguous relationship with the urban normative picture and with the encumbering ius commune of imperial origin." 57

\section{Municipal Statutes}

The vast political changes described above resulted in redactions of the municipal statutes. The processes of the criminal court and the penalties for crime developed in these statutes and in signorial decrees. It was common practice in territories under Visconti rule for the statutes to be reissued. ${ }^{58}$ Barnabò did not order a full redaction of the statutes, and the statutes of 1335 were reissued in 1371 and remained in force until $1392 .{ }^{59}$ Municipal law, however, was a living organism, and Barnabò allowed the Consiglio della città to form a committee

54 Grimaldi, La signoria di Barnabò Visconti, 84.

55 However one needs to exert caution when interpreting the medieval hierarchy of laws. As Paolo Grossi commented: “Non vi sono giuridicità di grado superiore e inferiore; non v’è un ordinamento più valido: il diritto universale, il diritto collaudato nei secoli, il diritto scientifico, può cedere di fronte alla piccola emersione locale. Non è una gerarchia delle fonti, è invece un gioco di rapporti fra ordinamenti che, convivendo e covigendo, si comprimono nella relatività della vita giuridica." Paolo Grossi, L'ordine iuridico medieval (Bari: Editori Laterza, 1995), 233-234.

56 Gamberini, "La forza della comunità," in Lo stato visconteo: Linguaggi politici e dinamiche costituzionali (Milan: Franco Angeli, 2005): 146.

57 Massimo Vallerani, "The Petition to the Signore and the Power of Mercy," in Medieval Public Justice, trans. Blanshei, 308.

58 Black, Absolutism in Renaissance Milan, 115.

59 Grimaldi, La signoria di Barnabò Visconti, 81. Book I was revised because it dealt with the relationships of the Gonzaga to the feudalità. 
which, together with a representative of the signore, could make reforms or changes to the statutes. The statutes would finally be redacted under Giangaleazzo as part of his broader administrative reforms, which aimed at achieving unity in the disparate lands of the Visconti state. He appointed two jurists, Paolo de Arzonibus and Giovanni de Carnago, both members of the Collegio dei giudici in Milan, to redact the statutes of Reggio Emilia, and the two-year-long project was completed in $1392 .{ }^{60}$

Concerning the criminal law, the 1392 redaction brought some changes, largely additions. Perhaps most importantly, the ex officio power of the judge appears to have been increased. ${ }^{61}$ Most penalties remained unchanged, though a few were expanded, and a new penalty for sodomites was institute in the statutes. ${ }^{62}$ Other changes included a series of new capitula that dealt with a variety of concerns, such as forbidding the Podestà and his judges to incarcerate anyone for crimes that did not merit corporal sentences. ${ }^{63}$

It is unknown whether-or how closely - these jurists worked with the city council. ${ }^{64}$ They certainly were not obliged to work with any form of representation from Reggio at all. The Lord of Milan could "with or without the council of the city of Reggio, establish, make interpret and declare decrees, reformationes, ordinances and statutes." ${ }^{65}$ If, in the communal period, city councils had been the ultimate arbiters of power, under signorial regimes, these bodies were generally not dismantled but their authority was greatly curtailed by new innovations. The authority to call them to meet, for example, could be appropriated by signori, together with the authority to override their decisions. ${ }^{66}$ At Reggio, the general administrative body was the Council of the Twelve convened by

6o Gamberini, "La forza della comunità," 138-139.

61 Gamberini, "La forza della comunità," 141. However we may wonder about the practical results of this provision, and how much of a departure it represented from current practice; see below in Chapter Two.

62 ASRe, Comune, Statuti del 1392, fol. 156v. The new penalty was death by burning. The 1335/1371 redaction had no specific penalty.

63 ASRe Comune, Statuti del 1392, fol. 156v.

64 Gamberini, "La forza della comunità," 140, and 140 n. 9.

65 ASRe, Comune, Statuti del 1335/1371, fol. 3r, quoted in Gamberini, "La forza del comunità," 138; cf. Grimaldi, La signoria di Barnabò Visconti, 84. "[Dominus] possit cum consilio et sine consilio civitatis Regii decreta, reformationes, ordinamenta et statuta condere, facere, interpretari et declarare."

66 Grimaldi, La signoria di Barnabò Visconti, 112. At Reggio, one of the most important functions of the Twelve was the election of the sindaco and the avvocato del comune, but the naming of these officers had to be confirmed by the Signore. 
either the Podestà or his vicar. ${ }^{67}$ Its members comprised the most elite of the citizens, a "minoranza nella minoranza." 68

In the balance of power between signore and city, local statutes were of great significance, not only legally but also symbolically, showing as they did a line of historical autonomy. They gave voice to matters of civic concern, kept alive urban self-government, and perhaps even placed some limits on princely authority. ${ }^{69}$ At Reggio, Barnabò's reordering of the hierarchy of laws meant that the statutes took second place to signorial decrees. But the community did not adhere to demands to insert these decrees into the book of statutes, and kept them in a separate volume instead - a defiant act that Gamberini has interpreted as a last resistance to the interference of the signore in the municipal law. ${ }^{70}$

\section{Foreign Rectors}

During the Visconti age, the most important officials of the city were the Podestà, the referendario, and the Capitano della Città. The office of the Capitano — which, in other cities, sometimes held parallel or even overlapping jurisdiction with the criminal judge of the Podestà ${ }^{71}$ —at Reggio held primary responsibility for defenses, also controlling the more or less continuous flow of

67 Grimaldi, La signoria di Barnabò Visconti, 111. The presence of oligarchies inside the governments of city-republics was not uncommon; Daniel Waley, "The Use of Sortition in Appointments in the Italian Communes," in Communes and Despots in Medieval and Renaissance Italy, eds. John E. Law and Bernadette Paton, 27.

68 The power of the Twelve was concentrated in the hands of between thirty and forty men who were continuously re-elected to their seats, a group of men Gamberini calls an "open oligarchy." The members of the Twelve changed every month, with four men chosen from each district of the city. These men came from families whose social standing grew during the fourteenth century and who also held important positions within the church; there were some new names among the men holding office, men who were apparently "selfmade." The citizen assemblies, the Twelve and the Forty, were not restricted to the old noble families of Reggio; Gamberini, La città assediata, 90-94.

69 Diego Quaglioni, "La legislazione del principe e gli statuti urbani nell'Italia del Quattrocento," in Principi e città alla fine del medioevo, ed. Sergio Gensini (Pubblicazioni degli Archivi di Stato 41) (Comune San Miniato: Pacini Editore, 1996), 3-4 and 15-16.

70 Gamberini, "La forza della comunità," $143-145$ and 144 n. 23-25.

71 In Florence, the office of the Capitano underwent a "transition from parochial responsibilities to general competence," and by 1415 he exercised general authority in criminal matters; Stern, Criminal Law System, 230. After 1376 in Bologna, the restored office of the Capitano del Popolo shared criminal jurisdiction with the Podestà, though the Capitano 
mercenaries, who constituted one of the marked features of the Reggian landscape at the end of the fourteenth century. He exerted some jurisdiction over the stipendiarii and he also took responsibility for maintaining order in the countryside, at least during the reign of Barnabò. ${ }^{72}$ The Podestà and Capitano were closely linked and served in place of the other, if one were ill or incapacitated..${ }^{73}$ The primary figures of the criminal justice system were the foreign Podestà and his criminal judge, who, during the Visconti age, were appointed to renewable terms of service by Milan. If Reggio maintained the practice of other communes, the public importance of the Podestà would have been underscored by the manner in which he swore his oath of office, publicly and in stages, in a sort of adventus ceremony. ${ }^{74}$

\section{$1 \quad$ Office of the Podestà at Reggio Emilia}

The Podestà and his criminal judge were vested by the signore with the merum et mixtum imperium for the terms of their office, exercising full criminal and civil jurisdiction over Reggio Emilia and its territories. ${ }^{75}$ Theoretically, the use of a foreign Podestà ensured that the law was enforced by someone without local feudal associations or vested interests in urban politics. ${ }^{76}$ The institution had evolved from the magistrates sent by Emperor Frederick I to oversee judicial

dealt particularly with cases of treason or conspiracy. Blanshei, "Cambiamenti e continuità nella procedura penale a Bologna," (forthcoming).

72 The duties and powers of the "Capitaneus et custos civitatis Regii" are expressed in the appointment of Galeaz de Porris; ASRe, Comune, reg. dei decreti, 1389-1404, fols. 20v-21v.

73 Gamberini, La città assediata, 259-261.

74 The adventus of the Podestà was designed to emphasize the honor of the city, and also his neutrality. Christoph Dartmann, "Writing and Political Communication in Italian City Communes," in The Medieval Legal Process: Physical, Spoken and Written Performance in the Middle Ages, eds. Marco Mostert and P.S. Barnwell (Turnhout: Brepols, 2011), 206; cf. Dartmann, "Adventus ohne Stadtherr-'Herrschereinzüge' in den italienischen Stadtkommunen," Quellen und Forschungen aus italienischen Archiven und Bibliotheken 86 (2006), 64-94.

75 Local officials judged minor infractions, particularly in cases of trespass and minor property damage. The court that oversaw such claims was presided over by a local judge, referenced in the records of the court not as iudex but as officialis (though the statutes refer to his position as iudex). The records for the court of dani dati survive from 1398 and from 1404 (ASRe, Archivi Giudiziari, Curie della città, Libri dei Danni dati o delle accuse). Book Three of the 1392 redaction and Book Four of the 1335/1371 redaction concern the rules and regulations of this bench. ASRe, Comune, Statuti del 1335/1371, fols. 4or-49r; ASRe, Comune, Statuti del 1392, fols. $157 \mathrm{v}-165 \mathrm{r}$.

76 Since at least the twelfth century, foreign governors and judges administered important affairs of communal politics and justice in northern Italian cities, traveling from city to 
institutions, but it could actually serve as a vehicle for the expansion of municipal autonomy if the city retained the freedom to choose the Podestà. ${ }^{77}$ Thus, as signorial regimes kept and repurposed this convenient tool, they sometimes appropriated from the city councils the authority to appoint men to these positions, using their own appointments to create a tool that extended their reach into subject territories. Even before the signorial period, it is doubtful that the system of foreign rectors ever really provided neutral, uncommitted tribunals. If Gandinus envisioned the "'unrivaled judge' ... who seeks truth and the punishment of crimes... in reality, the communal cities were divided internally, assigned diverse jurisdictions and roles to the foreign judges, imposed tortuous processes on the trials, distributed privileges to local cives, and granted to local jurists the power of intervention and enormous control over judicial events under the guise of the consilium sapientis." ${ }^{\prime 8}$

Under signorial regimes, the Podestà and his court sometimes occupied a nebulous political space between the authority of the signori who appointed them, and the municipal councils, whose policies directly affected their work. At Ferrara, the savi of the commune exerted control over legal procedure and amended civil and criminal law, ${ }^{79}$ though the commune's participation in issues of law and order declined by the fifteenth century. At Reggio, as we have seen, the plenitudo potestatis held by the Visconti meant that procedures and

city to hold limited terms of office, usually of six months. Daniel Waley, The Italian CityRepublics, 2nd ed. (London: Longman, 1978), 32.

77 Stern, Criminal Law System, 77.

78 Massimo Vallerani, "How the Inquisition is Constructed," 232. At Reggio, it is unclear how much control the consilium sapientis offered jurists, though there were clearly some advantages to using them. The consilia sapientis (unlike consilia pro parte) were solicited by the criminal judge and could protect him from rendering a politically inconvenient judgment. Consilia pro parte, however, tended to support the party that commissioned them. Blanshei, "Cambiamenti e continuità nella procedura penale a Bologna," (forthcoming.) In Reggio, references to such consilia are extremely rare, perhaps because of influence from Milan, where efforts had been made to forbid them in the criminal process by the 1340s. Padoa-Schioppa, "La giustizia milanese," 19-25. Giangaleazzo also banned them, because they could be used to avoid or reduce criminal penalties. Dean, Crime and Justice, 108. However, Jane Black has recently shown that efforts to forbid their use were not successful. Black, Absolutism in Renaissance Milan, 4. In Bologna, Sarah Blanshei found them frequently used in trials against alleged magnates, where sometimes as many as nine sapientes were consulted. Blanshei, Politics and Justice, 215-216. For a discussion of the problem of the use of consilia sapientis in the criminal courts, see Blanshei, "Cambiamenti e continuità nella procedura penale a Bologna," (forthcoming).

Dean, "The Commune of Ferrara," 192. 
laws of the statutes could be superseded at the will of the lord of Milan. And one critical means of influence remained the oversight of the Podestà's salary.

The salary of the Podestà in independent communes was generally set by the governing city councils. At Ferrara during Este rule, while the Podestà was chosen by the signore, the commune still made critical decisions that influenced the Podestà's office, such as his salary. ${ }^{80}$ This should be contrasted with the structure of the Podestà's salary at Reggio, which was set by the signore and over which the anziani of the commune had no direct control. When municipal councils became oligarchical, as at Siena, this ability to set the terms of office lent great power to the elites who held positions on these councils, and they maintained in this way control over the foreign offices. It was perhaps for this reason that Giangaleazzo would restructure the Podestà's salary at Reggio, ending the anziani's direct control over it. ${ }^{81}$ In 1386, he decreed that a third of the Podestà's salary should come from convictions. His reasoning, at least ostensibly, was so that "in our cities which have been newly acquired, these Podestà [should] show themselves to be ready and solicitous to punish wrongdoings, which before truly went unpunished." 82

Linking the Podestà's salary to condemnations was not by itself unusual: certainly similar arrangements existed elsewhere.$^{83}$ But in a place where the salary was already limited, as was the population and thus the potential pool of convictions, these arrangements left the Podestà little choice but to borrow money. Though it was illegal to do so, the Podestà at Reggio borrowed from those same local elites that served on the councils. These financial arrangements tied the Podestà at Reggio to the interests of the elites of the city. ${ }^{84}$ This posed an obvious problem for signorial control, and our limited evidence may suggest an increasing concern with the issue: a public announcement, was given on the last day of July, 1372, that no one should lend money or credit to any one from the familiares of the lord Podestà, under the penalty of ten

8o Trevor Dean, "The Commune of Ferrara under Este Rule," in City and Countryside in Late Medieval and Renaissance Italy: Essays Presented to Philip Jones, eds. Trevor Dean and Chris Wickham (London: Hambledon Press, 2003), 192-193.

81 Gamberini, La città assediata, 30 n. 16.

82 ASRe, Comune, Registri dei decreti, reg. 1385-89, July 17, 1386, 44v: “. . in civitatibus nostris noviter aquisitis quia cognitum ex ipsis ipsos potestates se prontos et solicitos exibere ad delicta punienda que antea bene transibant inpunita."

83 For example, at Siena under the Nine, the Podestà received a fixed sum for condemnations and arrests in addition to his salary. Bowsky, Siena under the Nine, 31.

84 Gamberini, La città assediata, 27-32. 
gold florins per offence. ${ }^{85}$ The same warning, given again ten years later on April 28,1382 , shows the penalty changed to the remission of the illegally lent money or item, as well as further punishment determined by the arbitrium of the Podestà. ${ }^{86}$ (One wonders how the Podestà would use his discretion in such a case!)

If these financial realities blurred the separation between the foreign rectors and the city they served, surely the extremely long terms of office that some of these men held reduced that separation even further. Podestà appointed in the first years of Visconti rule held their positions the longest. Thus Julianus Spinola was Podestà from $1372-1374$; Barnardo de Madiis from $1374-1381 ;{ }^{87}$ and Johannes de Garzonibus from at least the beginning of the first semester of 1382 until the end of the first semester of 1383 . It was not at all uncommon for the same Podestà to serve for two or three semesters, though lengthy terms like that of Barnardo are exceptional. These long terms of office may have been a way to make efficient the establishment of the new rule, particularly because the Visconti directly appointed the Podestà without a need for communal sanction of the choice. For example, in Bologna during the Visconti period, the same Podestà held office for three semesters during the first years, after which the rotation returned to normal. ${ }^{88}$ This may have been an efficient way of organizing a new Visconti administration in the conquered cities. It may also have been a reflection of a general practice for the offices to be filled at the time that seemed appropriate to the signore; indeed also at Milan in the same period, the time and duration of the appointments of the Podestà did not closely follow statutory norms. Many Podestà served more than one term, sometimes remaining in office for two or more years. ${ }^{89}$ Yet ultimately the Podestà, who might reasonably have been expected to serve as a conduit for Visconti control, or as a mouthpiece of the signoria on the periphery of the state, in fact became

85 ASRe, Comune, Provvigioni, July 31, 1372, vol. 3, 4r, and also ASRe, Comune, Provvigioni, July 31, 1372, vol. 4, 6v.

86 ASRe, Comune, Provvigioni, April 28, 1382, vol. 6 1382-86, fol. 2r.

87 While the office of Podestà was held by the same man for at least six years, the office of the Iudex Maleficorum had slightly more turnover. The notary appointed to the office of the Iudex Maleficorum also remained fixed during these years. I have found Bernardo named as Podestà in the books of inquisition trials from the second half of 1374 through 1380; I suspect he was also Podestà in 1381, as the Iudex Maleficorum remained the same for that year.

88 I am grateful to Sarah Blanshei for this observation.

89 Verga, "Le sentenze criminali dei podestà milanesi," 103. 
less a direct representative of Milan and more a key connection between city and lord. ${ }^{90}$

About the men who held this office, we know very little. At Reggio Emilia throughout the Visconti period, men from the noble families of Liguria and Piedmont figure prominently in official capacities in Reggio Emilia, as do, of course, the Milanese..$^{91} \mathrm{~A}$ branch of the Spinola family of Genoa, for example, provided three Podestà during the Visconti period: Julianus Spinola, appointed 25 April 1372 and in the office until the end of the first semester of 1374; Oppicino Spinola, who was Podestà from the first or second semester of 1398 until at least 1399, and possibly 1400; and Julianus Spinola, possibly the grandson of the earlier Julianus, who served most likely beginning in 1401 but definitely in the first semester of 1402, and was appointed again in the second semester of $1403 .{ }^{92}$ The office may have served as a stepping-stone to more illustrious appointments: Arrighino de Rivolla, Podestà at Reggio in 1385, was probably that same Arrighino de Rivolla who served as Podestà in 1393 in Milan. ${ }^{93}$ While the Podestà remained the chief magistrate through the fourteenth and early fifteenth centuries, under the Visconti, as under other signorial regimes at the end of the fourteenth century, the Podestà's authority decreased, and "the functions which he exercised under the Visconti were mainly judicial." ${ }^{\text {4 }}$

The Podestà was responsible for overseeing the appointment of otherofficials, whose work was critical to the courts, including the judges of the commune and the notaries appointed to various offices of the commune. ${ }^{95}$ In major

9o Ultimately, Gamberini concluded that the city seemed to regard the Podestà "non come al rappresentante di un potere lontano, da constrastare, ma al contrario come ad un importante elemento di mediazione nei suoi rapporti con l'esterno, in grado di dare autorevolmente voce alle istanze della comunità e soprattutto di tutelarne l'interesse." Gamberini, La città assediata, 32 .

91 Grimaldi, La signoria di Barnabò Visconti, 95-96.

92 ASRe, Comune, Registri dei decreti, reg. 1371-72, April 25, 1372, fol. 31v. The appointment of Julianus Spinola to the office of the Podestà in 1372 identifies him as "Dominus Julianus Spinulla de Luchulo, civis Janue."

93 See Verga's list of Milanese Podestà; Verga, "Le sentenze criminali," 136.

94 Bueno de Mesquita, Giangaleazzo Visconti, $5^{0 .}$

95 Eight notaries served the Podestà's retinue in total, four of which were assigned to the lieutenant of the Podestà, the judges of the commune, and the Knight of Justice. Also appointed were two notaries for the court whom oversaw issues of criminal damage and property damage. The elections were done by lot in the general council, before April in the first semester and before October in the second. Signorial power, however, could override such municipal elections, or cancel them altogether if the officials in question were to "retain their office by the will of the Lords." ASRe, Comune, Statuti del 1335/1371, fol. 13r: “... Et si ero potestas sive rector ad kalendas Ianuarii usque ad kalendas Iulii facere eligi 
cities like Genoa and Milan, the Podestà had many foreign judges in his court, appointed to civil and criminal cases, and he traveled with judges, notaries, police, and servants, all of whom he was responsible for paying out of his salary. Usually one of these judges also held the title of vicarius, which meant that the judge substituted for the Podestà if he were unable to be present for his duties. ${ }^{96}$ At Reggio, the Podestà's retinue was small. His vicarius was his criminal judge, the Iudex Maleficorum. This judge's responsibilities, evident in his oath of office, included overseeing the protection of the city, its property and its inhabitants. He was obligated to ensure that cases were decided according to municipal law.

\section{2}

\section{The Criminal Judge}

The criminal judge, or Iudex Maleficorum, a key figure in the Podestà's retinue, was the cornerstone of the criminal justice system. Unlike other cities like Bologna, where criminal jurisdiction was shared between the Capitano and the criminal judge, ${ }^{97}$ at Reggio, only one judge was appointed to major criminal matters. ${ }^{98}$ His particular importance at Reggio Emilia is underscored by the fact that he was also designated as the vicarius, who would step in should the Podestà be unable to fulfill his duties. The iudex maleficorum could intervene in any criminal matter unless specifically prohibited by the Podestà, who had the power to remove cases from his purview. ${ }^{99} \mathrm{He}$ was sworn to "attend and observe each and every statute and ordinance of the commune of Reggio, and to render decisions for all claimants [petentibus] according to the form of these statutes, and the good customs of this city of Reggio." He was apparently salaried by the Podestà directly, as he pledged "not to receive anything from the commune of Reggio for my salary," and part of his role was to support

officiales infrascriptos in conscilio [sic] generali ad sortem ante medium mensis Aprilis. Et si ero potestas sive rector ad kalendas Iulii usque ad kalendas Ianuarii facere eligi eosdem officiales ante medium mensis Octobris et nisi remanserit voluntate dominorum."

96 Caterina Santoro, Gli offici del Comune di Milano e del dominio visconteo-sforzesco (12161515) (Milan: Guiffrè, 1968), 227.

The office of the Capitano del Popolo, originally formed to govern cases concerning the popolo class, sometimes held an overlapping jurisdiction with the Iudex Maleficorum of the Podestà. Dean, Crime and Justice, 11; see above, n. 117.

98 The Capitano della Città had jurisdiction over mercenaries stationed at Reggio, but ultimately jurisdiction over crimes committed even by mercenaries went to the jurisdiction of the Podestà if the offense merited a blood penalty. See ASRe, Giudiziario, Libri delle denunzie, Nov 16, 1402, vol. 19. fols. 11r-14v, where the Capitano unsuccessfully challenged the right of the Podestà to try an assault case involving mercenaries. 
and advise the Podestà. ${ }^{100}$ His oath underscores the intention that the foreign rectors, but perhaps especially this judge, should be separate from the community and not financially dependent on it. His salary was not directly tied to condemnations, though after 1386 , it probably was indirectly, as he was paid by the Podestà.

There was no right of appeal from a sentence imposed by the criminal court, as Giangaleazzo made clear in $1387 .{ }^{101}$ But the court of the signore did function as a sort of supreme tribunal, to which those people who believed they had been victims of injustice could appeal. ${ }^{102}$ This was certainly not an appeals court in any technical way, and cases were not retried before the signorial court. In theory, the hope that the signorial court would overturn a conviction was open to all. Most people could not afford the expense of the trip or the legal costs of such an appeal, but they could deliver this complaint to the Podestà, who was obliged to send it to Milan within fifteen days of its receipt. Barnabò even took the unusual step of providing boxes where the inhabitants of Reggio could leave petitions to the signore. ${ }^{103}$ Probably the importance of the practice was as much symbolic as it was real, serving as a propagandistic, public statement of authority that made clear the overarching structure of signorial power in the justice system. ${ }^{104}$

100 ASRe, Comune, Statuti del 1335/1371, fol. 13r-v (see ASRe, Comune, Statuti del 1392 and BSR ms. 77, fol. 12r, with no substantial changes): "De juramento et officio iudicis Domini Potestatis et quis modus servandus sic in ratione reddenda. Iuro ego Iudex Potestatis civitatis Regii attendere et observare omnia et singula statuta et ordinamenta communis Regii et facere rationem omnibus petentibus secundum formam ipsorum statuorum et bonarum consuetudinum ipsius civitatis et ubi ipsa statuta et consuetudines deficerent secundum formam legis communis excepto quod non possim nec debeam aliquid recipere a communi Regii pro salario meo et bona fide consulam Potestati civitatis Regii et operam dabo quod Potestas adimplebit officium et sacramentum quod iuravit furtum de avere communis non faciam nec facienti consentiam ... Et possim ego Iudex qui ero deputatus ad maleficia intromittere me de causis ordinariis si michi expressum non fuerit inhibitum a Poteste vel Rectore."

101 ASRe, Comune, Registri dei decreti, reg. 1385-1425, February 21, 1387: “... nullus a sententiis criminalibus latis valeat appellare pro lege et decreto nostro servando et servari decreto faciendo facias in locis consuetis iurisdictionis tibi comisse publice divulgari et in volumine aliorum nostrorum decretum ad perpetuam rei memoriam inscribi et describi."

102 Grimaldi, La signoria di Barnabò Visconti, 116-117: "La Camera del Signore funzionò per tanto come un supremo tribunale, al quale tutti coloro che ritenevano per qualche speciale ragione di essere stati trattati con ingiustizia, avevano diritto di appellarsi. Il Signore poteva rivedere i giudizi, cancellare le condanne, trasformare e ridurre le pene."

103 Gamberini, La città assediata, 110.

104 Black, Absolutism in Renaissance Milan, 119-120. This direct intervention in justice was a feature of Barnabò's rule that was developed also by Giangaleazzo. During their reigns, as 
If we know little about the men who held the office of the Podestà, we know still less of the men who served as the criminal judges. While generally, the criminal judge was one of the officials who accompanied the Podestà and was selected by him, at Reggio Emilia under the Visconti, we might question the autonomy of the Podestà in making this decision. In the Visconti state it was common that judges came from the same town or city of origin as the Podestà, ${ }^{105}$ which perhaps tends to explain how the Podestà selected his court. But this was often not the case at Reggio. For example, two of the three criminal judges who served under the first Julianus Spinola hailed respectively from Parma and Trento (it is unclear where Aluysius de Beneditis came from), while Julianus himself was Genoese. Lanzaroti de Regnis of Milan, Podestà in 1390 and 1391, had a criminal judge from Parma. The second Julianus Spinola's criminal judge was from Cremona. In short, when it is possible to tell the cities of origin of these men, they do not seem to be connected. No criminal judge appears to serve under more than one Podestà, so it seems reasonable to assume that the Podestà still selected the criminal judge; however the disparate origins of the Podestà and judges may suggest that the candidates were recommended by Milan.

The criminal judges were deputized by the Podestà, usually together with other foreign officials. In a letter to the city announcing the appointment of a new Podestà, the lords of Milan required the "commune [of Reggio] and the men of our city" to concede to the Iudex Maleficorum, vicarius, and other judges "that jurisdiction and power which belongs to the office to which the Podestà would deputize them". ${ }^{106}$ A list from 1382 shows the Podestà Johannes de Garzonibus deputizing five judges, among which was Bartholinus de Camiziis de Cremona, deputized vicarius. ${ }^{107}$ Deputizing, however, is not selecting, and it is unclear how the individuals were chosen.

Black observed, justice was grounded on their power to overturn laws and rights, which supported an image of the signore as the champion of the poor and disenfranchised.

105 Santoro, Gli offici del Comune di Milano, 227.

106 As found in the appointment letter of Arrighino de Rivolla in 1385 : "... facimus, actimus et creamus mandantes comuni et hominibus dicte nostri civitatis quatenus ipsi Arighino ibidem nostro viro potesti in omnibus et singulis spectantibus dicte potestarie [sic] officio que nostra sint honoris ei status tamquam nobis pareant et intendant concedentesque iudici maleficorum vicarii et aliis iudicibus iurisdictionem omnimodam et potestatem ad illa condicenda officia ad que dictus nostra potestas ipsos deputabit." ASRe, Comune, Registri dei decreti, reg. $1385-89$, fol. $4 \mathrm{v}$.

107 The Iudex rationis was also appointed (also iurisperitus), together with three other officials, respectively from Cremona, Parma and Modena; ASRe, Comune, Provvigioni, 13821386 , 2 or. 
The men who held this office had legal training, though the level of their training varied and the notaries of the criminal court were sometimes inconsistent in the titles they attributed to the judges. There was no fast rule defining the legal background required for the practice of law: in Bologna, a five year course of study was necessary for one seeking a position as a communal judge, but in Padua, a person desiring to serve as a judge was only required to possess legal books, libri legales, and a basic familiarity with the law. ${ }^{108}$ At Reggio, judges had varied legal backgrounds. The above-mentioned Bartholinus was described by the notary of the criminal judge as iurisperitus. In 1388 , the criminal judge was Antonius de Pontremulo, who is sometimes designated in the records of the criminal court as licentiatus in iure civili, ${ }^{109}$ and other times as legum doctor. ${ }^{110}$ In much the same way, Ludovicus Pagana de Montericco, criminal judge in 1396 and 1397, was indicated sometimes as in iure civile publice licentiatus ${ }^{111}$ but in the next year, the notary listed him as in utroque iure licentiatus. ${ }^{112}$ Other Iudices Maleficorum are listed as iurisperiti, legum doctores, or even as doctores utriusque legis. The men who held this office came from various parts of the Visconti state, including Cremona, Valentia, and Parma.

Like the Podestà, the judges often held longer terms of office than the statutes proscribed. Rolandino de Zamoreis de Parma, for example, held office for at least four and a half years beside Bernardo de Madiis, who served as Podestà for at least six long years, from 1374 to 1380 , and possibly 1381 . But frequently, the Podestà who held long terms of office had more than one criminal judge during their tenure. At least three different men held the office of criminal judge during the seven consecutive semesters of the first Julianus Spinola, from 1372 to $1374,{ }^{113}$ while Antonius de Tremilicio, Podestà from the second semester of 1391 until the end of the second semester of 1392, had three different judges, one in each semester of his appointment.

On the basis of this admittedly sparse evidence, one could suggest that on the whole, criminal judges were highly educated, not infrequently holding the doctorate of laws, or even the highest title of doctor utriusque iuris, though

\footnotetext{
108 Ascheri, Laws of Late Medieval Italy, 325.

109 ASRe, Giudiziario, Libri delle denunzie, n.d. 1388, vol. 10, fol. 1r, passim, as designated by the notary Guido de Bebbio.

110 ASRe, Giudiziario, Libri delle denunzie, 1388, vol. 11, fol. 11., passim; ASRe, Giudiziario, Libri delle denunzie, 1388 n.d. vol. 12. fol. 18r, passim.

111 ASRe, Giudiziario, Libri delle denunzie, October 25, 1396, vol. 16, fol. 3r, passim.

112 ASRe, Giudiziario, Libri delle denunzie, 1397, vol. 17, fol. 1r, passim.

113 This is clear from the surviving trial records, where two of the names are found, and more clearly from the record of syndication of his terms, in which all five men are clearly named. ASRe, Giudiziario, Atti e processi, 1374, fol. $65 \mathrm{v}$.
} 
the conflicting titles sometimes recorded by the notaries are of concern. Particularly those judges holding the doctorate of laws—of whom there were at least five in the years under consideration-must have been from families of considerable wealth. Four of these five highly educated judges held the office only for one semester, suggesting that perhaps this appointment was part of a cursus honorum leading them to other, presumably more lucrative or prestigious, offices elsewhere. The men all came from some part of the Visconti dominion, but usually they hailed from different places of origin than the Podestà and their terms did not always match closely with the Podestà. The Podestà deputized the judges, but may not have had much autonomy in selecting them.

\section{$3 \quad$ Notaries of the Criminal Court}

Not to be overlooked is the position of the notaries appointed to the criminal judge - after all, it is they who, in a very literal way, controlled the narrative of the court's function, and it is they who provided the evidence that this and every other archival study rests upon. At Reggio, the foreign notaries of the criminal judge were appointed directly by the signore. Regina della Scala appointed, for example, Gasperolus de Robiate, a citizen of Milan, to replace Rugerius de Bichignis as the notary appointed to the criminal judge at the same time she appointed Julianus Spinola as Podestà. Gasperolus swore his oath of office on 29 April, 1372, before Johannes de Baldichivis, the vicarius and presumably also the Iudex Maleficorum. ${ }^{114}$ It was Regina who revoked Rugerius's appointment and conceded it to Gasperolus, naming him to a one-year term. The notaries' terms of office were therefore not tied to those of the Podestà, and sometimes they served under more than one judge or Podestà. The criminal judge Rolandino de Zamoreis de Parma kept the same notary for at least two of the years he served in office-Aluysino de la Frixeria de Cremona was the notary for the Iudex Maleficorum from 1375 to 1378, having served also under Rolandino's predecessor, Nicolino de Carienus de Cremona.

This practice may reflect a concern with corruption. Certainly many communes instituted systems designed to ensure the accuracy and veracity of notarial accounts, having multiple foreign notaries appointed to the same bench, for example. The statutes did call for two notaries to be appointed to the criminal judge, but it is not clear if this always happened at Reggio- the appointment letters that survive name only one notary, and the surviving

114 ASRe, Comune, Provvigioni, 1372, vol. 4, fol. 1 . 
registers seldom overlap. ${ }^{115}$ When the notary was syndicated at the end of his term, the Podestà appointed the judge who would do so.

\section{$4 \quad$ Other Foreign Officials}

At Reggio under the Visconti, more and more offices were filled by foreign officials. These foreigners were advocates, bookkeepers, notaries, constables, and members of many other professions. ${ }^{116}$ They held offices that were traditionally not open to locals as well as new positions. Barnabò Visconti created a new foreign racionator, who worked together with a local racionator ${ }^{117}$ to examine the commune's bills and submit copies to the Milanese court every month. They also supervised the calculation of the salaries of the military, including the stipendiarii and the cavalieri, and validated and paid the other bills of the commune, coming in time to supersede the earlier office of the massario.118 Another new office was that of the referendario, the supervisor of the general administration of the commune, who represented the signore and his interests, and was responsible for making reports to Milan. ${ }^{119}$ Indeed his close supervision was equivalent to supervision of municipal matters by the signore. ${ }^{120}$

The concept was always the same, filling important positions with men who owed their appointments to Milan in an effort to keep control over the major administrative functions of subject territories without restructuring. The creation of new foreign officers to aid Milan's supervision of municipal affairs lends perhaps added significance to the decision to directly appoint notaries to the criminal court rather than leaving that decision to the Podestà.

115 For example see ASRe, Comune, Registri dei decreti, reg. 1371-72, fols. 31v-32r; ASRe, Comune, Registri dei decreti, reg. 1372-75, fol. 41v, ASRe, Comune, Provvigioni 1376, vol. 4, fol. $1 \mathrm{r}-\mathrm{v}$.

116 Grimaldi, La signoria di Barnabò Visconti, 96.

117 The local racionatores were usually citizens elected in the general council. Grimaldi, $L a$ signoria di Barnabò Visconti, 98-99.

118 Massarii did continue to serve a broader role in some of the smaller communes under Reggio's jurisdiction throughout the fourteenth century; for example, in 1394, Augustus Rangnus served as consul and massario of the commune of Bianello, which was under Reggio's jurisdiction. ASRe, Giudiziario, Atti e processi, October 18, 1394, unnumbered folios.

119 Grimaldi, La signoria di Barnabò Visconti, 101.

120 Federico Del Tredici, "Lombardy under the Visconti and the Sforza," in The Italian Renaissance State, eds. Gamberini and Lazzarini, 160. 


\section{The Lords of the Contado and the Question of Jurisdiction}

Control could not be established solely by appointing foreign officials. The feudal nobility of the contado played an important role in framing jurisdictional questions outside the city. Reggio had at least a hundred functioning, armed castles in its diocese at the end of the fourteenth century, only about ten of which were actually held by the Visconti. ${ }^{121}$ Strong local families controlled the dangerous, isolated roads and passes that were necessary to connect the territories. Rural communes, represented to the city by their elected consuls, could serve as "the vehicle used by local élites to establish dominance over their neighbours,"122 and the rural landscape provided possibilities for the acquisition of power. Control over highways, control over waterways, canals and aqueducts - in short, control over the resources that made the city functionaloften required negotiations with the powerful families of the contado. The family da Roteglia, through whose land the Secchia river flowed, forced concessions from the commune in exchange for uninterrupted supply of water. ${ }^{123}$ Likewise, the Dallo held the mountain passes in the southern part of the territory, and their control over these important crossings into the Garfagnana and into Tuscany gave them a great deal of power, if not imperium. ${ }^{124}$

For the signori of Milan, simply appointing officials to oversee the highways or the dispensation of justice in these areas was a weak solution. The Capitano della Città, it is true, was charged with maintaining some order in the territory, and the later creation of an office of the Capitano del Devieto to patrol the highways and rural areas shows efforts to keep the peace. But to maintain control, the cooperation of rural lords needed to be coopted, and this was done by means of grants that formalized and legitimized control of their territories. Men and connections could be exchanged for privileges and autonomy, offering "the lesser power an ambiguous position somewhere between allegiance and subjection." 125 Giangaleazzo would ultimately come to use the fief as an instrument of government, delegating jurisdictions in return for subordination, and seeking to both entwine his interest with these lords while also

121 Gamberini, La città assediata, 110.

122 Chris Wickham, "Rural communes and the City of Lucca," in City and Countryside in late Medieval and Renaissance Italy, eds. Trevor Dean and Chris Wickham (London: Hambleton Press, 1990), 11.

123 Gamberini, La città assediata, 220-221 and 221 n. 238.

124 Gamberini, La città assediata, 181-185.

125 Federica Cengarle, “Lordships, Fiefs, and 'Small States,' " in The Italian Renaissance State, eds. Gamberini and Lazzarini, 290-291. 
limiting their autonomy. ${ }^{126}$ The families perhaps viewed these grants as progress towards an ultimate goal of full autonomy, but from the perspective of the signori, too much autonomy in the contado would isolate the cities, so it was a fine line to walk. ${ }^{127}$

Possessing a castle did not necessarily imply jurisdiction. Jurisdiction was exercised by the criminal court of the Podestà at Reggio throughout the diocese except in the territories of lords who had received concessions of merum et mixtum imperium. Categories of imperium are distinguished in the Digest, where simple ("merum") is criminal jurisdiction, ${ }^{128}$ and the merum et mixtum imperium was the pinnacle of power and autonomy. ${ }^{129}$ At different times and in different areas, some of these families, like the Canossa, or the Gonzaga, or the Correggio, did have the full concession of merum et mixtum imperium in the lands immediately surrounding their castles. ${ }^{130}$ But in practice the boundaries of the jurisdictional questions outside the city could be shadowy.

The famous case of Gabriotto da Canossa, which is well attested in the sources and analyzed by both Grimaldi and Gamberini, serves as an excellent example of some of these problems. Gabriotto held merum et mixtum imperium in his lands. ${ }^{131}$ His murder in 1385 resulted in a contentious trial in which the city of Reggio Emilia stalled the condemnation of his assassin, perhaps as a result of an outright collusion of the city with the murderers to get rid of this locally powerful figure. ${ }^{132}$ Ultimately it took direct intervention by Giangaleazzo Visconti to have the culprits executed. Yet three years later

126 Cengarle, "Lordships, Fiefs, and 'Small States,' " 296-297.

127 Gamberini, La città assediata, 177-178.

128 Francesco Maiolo, Medieval Sovereignty: Marsilius of Padua and Bartolus of Saxoferrato (Delft: Eburon Academic Publishers, 2007), 153-154. The mixtum imperium refers to civil matters concerning property. The Bolognese jurist Odofredus equated jurisdiction with the merum imperium.

129 Giorgio Chittolini, "Infeudazioni e politica feudale nel Ducato visconteo-sforzesco," in his La formazione dello Stato regionale e le istituzioni del contado: secoli XIV e XV (Turin: G. Einaudi, 1979), 38 .

130 Gamberini, La città assediata, 196 and 210.

131 Gamberini, La città assediata, 171-174. The Canossa decended from a vassal of Matilda, who died without direct heirs. In 1185, Frederick I conceded fiefs to them at Canossa and Bianello, among other places. Eventually the Canossa, who held jurisdiciton from Enza to Crostolo in the base of the Appenines, would divide into separate branches of the family. Among the places that Gabriotto held were Canossa and Bianello, as well as the villae of Caviano, Bibbiano, Corniano, Calinzano, Castione, Sassoforte and Roncolo.

132 About this process, and the idea of collusion, see Chapter Three. For an analysis of the trial and its implications see especially Gamberini, La città assediata, 40-51, and also Grimaldi, La signoria di Barnabò Visconti, 148-152. The record of the trial is found in 
in the Villa de Castelis (in the territory of Gabriotto's heirs at the castle of Montevetro) when Benevenuta, wife of a certain Marcocius, was murdered by her husband in her home, ${ }^{133}$ the municipal court was very quick to claim jurisdiction and the subsequent trial became a vehicle to contest the heirs' claims to inherit their father's imperium. Marcocius objected that the court at Reggio could not proceed against him because he was a man "accustomed to obey and used to obey the late lord Gabriotto, and now obedient to his sons." The castle of Montevetro was in the jurisdiction of Gabriotto's sons, and thus the court should not proceed further. ${ }^{134}$ Various evidence was introduced, including a concession of imperium from Carlo IV of Luxembourg, but the problem was that while Gabriotto's imperium could be proven at Canossa, the status of the castle of Montevetro-which Gabriotto himself had built only thirty years earlier-was not clear.

Gamberini analyzed the tortured logic that summed up the city's argument for jurisdiction at Montevetro. The argument flew in the face of Giangaleazzo's explicit acknowledgments of the rights of Gabriotto's heirs. The jurist writing a consilium on behalf of the city's claims could not ignore the decree of the lord of Milan, so instead he paraphrased Giangaleazzo's letters with the innocuous statement, "[the heirs complain] that they have been treated badly; the Lord orders that they should be treated well."135 Perhaps not surprisingly, the case would ultimately be settled once again with intervention from Milan to stop the process, and the city's bid for jurisdiction failed. Whatever happened to Marcocius, murderer of his wife, is unknown; Benevenuta's death became a pretext for an argument over jurisdiction. This episode reveals the difficult position of the court of the Podestà at Reggio, which was empowered by the signore, but entangled in the interests of the city.

Given the importance of the exercise of jurisdiction as a statement of power, one wonders how inhabitants of contested areas understood authority. The witness testimony from Marcocius's trial may give us some sense of how jurisdictional power was identified. The judge, trying to establish whether Gabriotto had been accustomed to exercise the merum et mixtum imperium at Montevetro, questioned witnesses on a series of behaviors that would indicate whether he in fact held it. Jurisdiction as defined by the observation of contemporaries provides a particular perspective on jurisdiction. In the words of

ASRe, Giudiziario, Libri delle denunzie, November 13, 1385, 7.82r-83v. The incident is also recorded in the Chronicon Regiense (Gazata, Chronicon Regiense, col. 92).

133 ASRe, Libri delle denunzie, 12.35-45, June 22, 1388.

134 Gamberini, La città assediata, 46.

135 Gamberini, La città assediata, 49; ASRe, Giudiziario, Libri delle denunzie, 1388, 12.35r-45v. 
witnesses like the notary Jacobus de Castellis, Gabriotto collected fines and everyone obeyed him; the witness did not use the terms for imperium but he described the behaviors of those who wielded it. Another witness, Bartonius de Castagneto, was asked

if he ever saw [Gabriotto] exercise anything of the merum imperium. He responded that in the time when Lord Barnabò was lord of Reggio, one person had been hanged there [at Montevetro]. Asked [for what reason] he was hanged, he responded that [the man who was hanged] had been already there [at Montevetro] [in Gabriotto's employment] and he had fled, and it was said to Lord Gabriotto that [this man] wanted to betray him. Asked if he was condemned by any judge, [the witness] said that he did not see any judge but he saw very well the man taken from Montevetro and led to the gallows and hanged..$^{136}$

Another witness recounted another hanging, but also recounted an episode in which Gabriotto sent two of his vassals (vasalibus) who had committed a crime to be tried by the Podestà of Parma. The judge in the interrogation used the terms iurisdictio or iurisdictio cum sanguine and merum imperium interchangeably.

Even among those lords who had merum et mixtum imperium, it was not necessarily always convenient to assert it. Gabriotto sent his own men to be judged in Parma. Similarly, in 1397, Guido da Fogliano, of the powerful family that once had even held the signoria of Reggio, chose to send the murderer of one of his retainers to be tried at Reggio. ${ }^{137}$ Guido wanted the matter decided at Reggio, and went so far as to hide an official behind a curtain to listen while Guido, with a false offer of peace, elicited a confession. ${ }^{138}$ The peace offer was contingent upon the willingness of the murderer to execute one of his accom-

136 ASRe, Giudiziario, Libri delle denunzie, August 22, 1388, vol. 12, fol. 39r.: "Interrogatus si vidit unquam aliquid meri imperii exercere respondit quod tempore quo Dominus Barnabòs erat dominus Regii fuit ibi suspensus unus. Interrogatus quare fuit suspensus respondit quod iam ibi fuerat ad stipendum et fugerat et dictum fuit dicto Domino Gabrioto quod voluerat ipsum prodire. Interrogatus si fuit condemnatus per aliquem iudicem, respondit quod non vidit aliquem iudicem sed vidit bene ipsum extraheri de Montevetri et duci usque ad furcas et suspendi. Interrogatus si vidi nec audivit fieri aliquam alia iusticia respondit quod non..."

137 On the Fogliano family, see Gamberini, La città assediata, 227-242.

138 ASRe, Giudiziario, Libri delle denunzie, September 10, 1397, vol. 17, fol. 9v. This episode is discussed further in Chapter Four (on torture) and Chapter Five (on peace agreements). 
plices in the homicide. As Guido said during the staged negotiations, "I cannot do justice for you, who killed my man." Guido told Antonius that he would prefer to make peace with him rather than to send him to judgment in Reggio, because "if I cause you to be hanged, there is nothing [in it for me], and I will not be enriched at all."139 Antonius relented and entered into the negotiations, and with testimony to this conversation as the central piece of evidence, the judge in Reggio ultimately ordered Antonius to be executed.

We might wonder why Guido said that he could not render judgment himself on someone who killed "his man", while Gabriotto was ready to hang a man he suspected of plotting against him, even while he sent others to judgment at Parma. Trevor Dean analyzed Guido's case in terms of friendship and enmity, and it is certainly clear that Guido's fake negotiations involved coercing Antonius to kill one of Guido's enemies, transforming Antonius into "a tool of private vengeance."140 This clearly seemed reasonable to Antonius, who accepted the proposition without any indication of surprise at the terms, but even if Guido seemed in Antonius's eyes to have the right to settle the case this way, Guido himself went to great lengths to have the case tried by the criminal judge in Reggio. It certainly is not surprising that people without legal training had difficulty distinguishing between the concepts of the ius castri and the merum imperium.

The very people who exercised political power in the contado were those same people who served as Podestà and judges in cities. The machinations of Guido da Fogliano and Gabriotto da Canossa were possible becaues they both exercised political power in the contado, and because they belonged to the class that held the offices of foreign rectors described above. Therefore Guido da Fogliano knew to carefully connive to acquire the appropriate amount of evidence to persuade an urban judge, while Gabriotto da Canossa-formerly Podestà at Cremona, Brescia, and even Milan, ${ }^{141}$ in which role he presumably maintained the strict procedural requirements of the statutes-led a man to hanging without a trial in the isolated realm of the castle that he himself built. Jurisdiction and imperium were carefully defined legal concepts that conferred

139 ASRe, Giudiziario, Libri delle denunzie, September 10, 1397, vol. 17, fol. 9v.: “. . qui Guido dixit si facerem te suspendi nec aliud esset et nichil essem lucratus..."

140 Trevor Dean, "II's a fine thing trusting in you, Guido!' Dissimulation in a Criminal Interrogation, Reggio, 1397," in Mantova e il Rinascimento italiano: Studi in onore di David S. Chambers (Mantua: Sometti, 2011), 296.

141 Gamberini, La città assediata, 117 . 
very real power and had a wide range of uses, but legal ideas of jurisdiction were not necessarily interchangeable with the recognition of authority.

\section{Criminal Jurisdiction and the Reporting of Crime}

Because of the importance of public exercise of the merum imperium, reporting major crimes to the foreign judge was obligatory. The public nuncio was obligated to make regular announcements in "customary public places" about the duty of neighborhood captains and consuls in the contado to inform the criminal judge "about homicides, assaults, quarrels, fights and whatever other crimes which happen to be committed and done in their borders ..."142 These announcements surely also served as public assertions of jurisdiction.

The officials charged with reporting crime were local citizens, not in the direct employ of the criminal judge. The election process for the neighborhood captains is not described in the statutes, however the occurrences of names in the court records would suggest that these men held month-long terms. Though the office rotated frequently, the same men tended to hold the position repeatedly (similar to the rotation of seats on the city councils). Of the sixty-four cases initiated by the captain of the neighborhood of Maior Ecclesia for a period of seventeen years only twenty men held that position. ${ }^{143}$ Outside the city, the obligation to report crime generally fell to consuls or massarii of the communes. These men could adjudicate less serious conflicts themselves, but they did not have the authority to hear major felonies. ${ }^{144}$

Probably because reporting crime, perhaps especially in the contado, underscored the jurisdiction of the municipal court over the territories, the neglect of this duty constituted a serious criminal offense. ${ }^{145}$ For all officials, urban or rural, whether consuls, massarii, or neighborhood captains, failure to denounce crimes within four days of their commission meant punishment "with a fine of a hundred soldi Reggian lire (hereafter R.L.) for every instance, to

142 ASRe, Giudiziario, Atti e processi, April 25, 1383, fol. 431r-v.

143 The sixty-four cases are trials by inquisition dating from July 8, 1374 to January 10, 1390. On the oligarchical nature of the councils, see Gamberini, La città assediata, 90-94.

144 ASRe, Comune, Statuti del 1335/1371, fols. 22v-23r: "Quod consules villarum districtu Regii teneantur venire semel in anno et securitates prestare Domino Potestati, et quod ius non reddent in suis comunis, et de compromissis non fiendis extra civitatem."

145 ASRe, Comune, Statuti del 1335/1371, fol. 3or, and 1392, 150v: "De pena consulis vel massarii alicuius terre non denunciantis maleficium in terra sua." 
be paid from his own wealth."146 Accusations of neglect against these officials are rare, and when they occur, they often seem connected to political conflict. Failing to denounce crime to the municipal court could be an implicit claim of criminal jurisdiction, and rebellion against the jurisdiction of the city was a strategy in a never-ending game for political autonomy. ${ }^{147}$ Charges of neglect involving personal liability were more common for the private officials of the jail than for neighborhood captains of the city or the officials of the contado, like the massarii or consuls of rural communities under Reggio's jurisdiction. ${ }^{148}$

When the inhabitants of Reggio and its territory were victims of crime, the captains and consuls provided the most obvious mechanism by which criminal activity might be denounced. Yet this still rested on the willingness of individuals to seek recourse from formal, municipal justice, and so "it very often happens that many crimes are committed about which the Lord Podestà has no notice..."149 Therefore, in a shift that reflects the growing reliance upon the opinions of doctors of medicine in northern Italy, reporting was also made obligatory during the fourteenth century for medical professionals, or for

146 ASRe, Comune, Statuti del 1392, fol. 150v: "Item, si aliquod enorme malleficium fuerit perpetratum in aliqua terra districtus Regii et consul vel massarius eiusdem terre dictum malleficium non denunciaverit potesti vel eius iudici vel militi infra quatuor dies post comissum malleficium quod statuimus et ordinaminus ipsum denuntiari debere puniatur dictus consul vel massarius si consul non esset pro qualibet vice de suo proprio avere in soldis centum Rexanorum et idem servetur in massariis seu capitaneis vicinorum civitatis et burgorum." The last provision of this statute which institutes a penalty for neighborhood captains was added in the 1392 redaction - no penalty was set forth in the 1335/1371 redaction for neighborhood captains, but this obvious oversight was then corrected. ASRe, Comune, Statuti del 1335/1371, fol. 3or.

147 For example, in 1389, the consul of Correggio was placed under ban for his negligence and subsequent contumacy. ASRe, Giudiziario, Libri delle denunzie, February 11, 1389.

148 ASRe, Comune, Statuti del 1335/1371, fol. 3or, and 1392, 150v: "De pena consulis vel massarii alicuius terre non denunciantis maleficium in terra sua."

149 BSR, Statuti, ms. 77, fols. 67v-68r. The full text of the statute reads: "Quoniam rei publice interest ut malleficia non remaneant impunita et sepissime contingit quod multa malleficia committuntur de quibus Dominus Potestas nullam habeat noticiam statutum est quod quilibet medicus et barberius speciarius et quis alia persona que se impedit de medicando vulneratos teneatur et debeat sub pena librarum viginti Rexanorum pro quolibet et qualibet vice denuntiare Domino Potestati vel iudici malleficorum omnes illos vulneratos sive percusos quos medicaverint ea die vel sequenti qua inceperint medicare si fuerint in civitate et si in episcopatu vel districtu infra quinque dies et quod Dominus Potestas teneatur in principio sui officii amonere omnes medicos barbarios et spiciarios [sic] de presenti statuto et eis sacramentum deffere de denunciato quoscumque medicaverint." 
anyone who treated suspicious wounds. ${ }^{150}$ It was not uncommon for physicians in northern Italian cities to provide some service to the state, or to provide assistance to the criminal court, ${ }^{151}$ though the obligations of physicians to denounce suspicious injuries or deaths was still by no means universal. The late medieval Florentine statutes do not compel physicians to denounce crime, for example, ${ }^{152}$ while in Venice, physicians were expected to act as informants to police powers. At Reggio Emilia, a statute requiring physicians to report injuries is lacking in the $1335 / 71$ and 1392 redactions of the statutes but appears in the redaction of 1411 under the rubric, "That doctors and surgeons are bound to denounce those whom they treat."153 The obligation to report the suspicious injury was immediate, either on the day of treatment or the next day, with five days allowed to those reporting from outside the city.

While the 1411 redaction postdates Visconti control at Reggio, it is possible that this provision was in effect long before, as physicians were already in public employ at Reggio and undertaking many other public duties, like plague control. Physicians at Reggio were already involved in post-mortem examinations and in the provision of medical consilia to the criminal judge during the Visconti period. ${ }^{154}$ This insistence on denunciation from medical professionals indicates increasing concern with the prosecution of crime, and further emphasizes the recognized importance of professional, disinterested denouncers.

The statute requiring medical practitioners to report suspicious wounds begins with the maxim, "it is in the public interest that crimes not remain unpunished...," clearly linking physicians' obligations to the criminal court with the larger agenda of inquisitorial justice. The concern was a serious one, and the Podestà was obligated at the beginning of his office to warn all "doctors,

$15^{\circ}$ BSR, Statuti, ms. 77 , fols. $67 \mathrm{v}-68 \mathrm{r}$, quoted above at n. 149 .

$15^{1}$ Venetian physicians, in return for a public salary, in addition to reporting crime and offering medical consilia to the criminal court, also offered free services to the public and advice to the city on plague control. Guido Ruggiero, "The Cooperation of Physicians and the State in the Control of Violence in Renaissance Venice," Journal of History of Medicine and Allied Sciences 33 (1978): 156-66.

$15^{2}$ Katherine Park, Doctors and Medicine in Early Renaissance Florence (Princeton: Princeton University Press, 1985), 96.

153 BSR, Statuti, ms. 77, fols. 67v-68r: "Quod medici et barberii teneantur denunciare illos quos medicant."

154 For a full consideration of physicians' activities in the criminal court at Reggio Emilia, see Joanna Carraway Vitiello, "Forensic Evidence, Lay Witnesses, and Medical Expertise in the Criminal Courts of Late Medieval Italy," in Medicine and Law in the Middle Ages, eds. Wendy J. Turner and Sara M. Butler (Leiden: Brill, 2014), 133-156. 
surgeons and apothecaries" about the law, and "to have from them an oath concerning the denunciation of those whom they treat." 155 Failure to make a denunciation was penalized by a fine of 20 pounds R.L. for each occurrence, a significant penalty, though not as severe as the penalties imposed upon negligent neighborhood captains or consuls. This difference underscores the particular concern that captains or consuls neglecting to denounce felonies to the criminal judge may have been engaged in other attempts to usurp jurisdiction, something that seems an unlikely motivation for a physician.

The role of the officials who reported crime-neighborhood captains, massarii, and consuls - was also investigative. Officials presented the judge not simply with names of suspects to investigate, but with the necessary substantialia of the crime. This would become the foundation of the narrative denunciation, or statement of charges, which began the inquisition. While these men worked with the Podestàs court, they were not agents of it. Their role was something of a mixture between incipient public prosecutors and police.

The criminal judge clearly expected that crime reporting would entail initial investigative legwork. In 1394, Augustus Rangnus, consul and massario of the commune of Bianello in the jurisdiction of Reggio Emilia, appeared before a deputy of the Iudex Maleficorum to present a denunciation of a theft. He himself had learned of the theft through hearsay (audivit dici), and though he had gone as far as preparing an estimate of the damages, he could not identify a culprit. ${ }^{156}$ The judge therefore ordered him to go back to his territory to conduct further inquiry, allowing him a week for this task, 157 but when he returned on the appointed day, he was still unable to identify a suspect. The judge sent him away, telling him to return and make a denunciation if in the future he managed to discover the guilty party. On that same day, the victim of the crime, Christoforus de Cosselis, also appeared, and, when asked under oath if he knew who committed this crime, he responded that he did not know. ${ }^{158}$

155 BSR, Statuti, ms. 77, 67v-68r.

156 ASRe, Giudiziario, Atti e processi, October 13, 1394, unnumbered folios. The notification was produced in writing and in fact, it was referred to as a denunciation, though it notified the court of a crime, not a suspect.

157 ASRe, Giudiziario, Atti e processi, October 13, 1394, unnumbered folios: “... cui Augustino praesens dictus iudex precepit quatenus vadat ad inquirendum si potest reperire patratores huius furti et quod die sabbati proxima futura que erit dies xx presentis mensis octobris debeat comperarere coram eo ad referendum quicquid invenerit de furto praedictio."

158 ASRe, Giudiziario, Atti e processi, October 13, 1394, unnumbered folios: "Die superscripta. Constitutus coram superscripto Domino Vicario et Iudice Mallificorum superscriptus Christoforus de Cosselis occaxione superscripti Ancutini eidem furati et interrogatus per superscriptum dominum vicarium et iudicem mallificorum per eius sacromentum si scit 
The judge then ordered the victim himself to go and make his own inquiry, and if he discovered a guilty party, to report this to the court. The judge's order to the victim to investigate the matter further is very unusual, but his order to the consul underscores the investigative function of that office.

The judge's role in investigation usually began when he took up the denunciation made by his officials which already included the basic facts at hand, and then carried out an inquiry to examine the facts in more detail. When, in 1382, a corpse was discovered outside the town of Albinea, the discoverer, "greatly disturbed, sad and afraid" at his discovery, "announced this thing to the consul of [Albinea] ... and to the castellan, which castellan sent (some) from his men to guard the cadaver that night, and who afterwards carried the cadaver to the church."159 The local men identified the body as that of a man named Zanardus. They remembered one snowy night nearly a month before, Zanardus had been gambling in the tavern. He left to borrow some money from the Bishop, but he never returned.

The consul would later send notice to the judge at Reggio that a corpse had been discovered, but it was the judge who interrogated the witnesses to determine whether the deceased had met with foul play. He interviewed at least five witnesses who had viewed the body when it was laid out in the church, and the witnesses gave specific testimony about the damage done to the corpse, testifying that to them, it appeared that the damage to Zanardus's body had been done by animals. The witnesses were of the opinion that Zanardus had wandered off, quite drunk, and had frozen to death in the snow. ${ }^{160}$ The judge's questioning was designed to test that conclusion, and he focused on four points: the condition of the corpse; whether Zanardus had any enemies; whether anyone had mysteriously disappeared from Albinea after Zanardus went missing; and whether any of the witnesses harbored any suspicion of foul play. ${ }^{161}$ The local men were convinced that the death was an accident; the judge played a sort of 'devil's advocate' to test the strength of their conclusions.

quis eidem furtiverit dictum Ancutinem suo sacromento dixit se nescire et si scieret bene denunciaret cui Christoforo prasens audenti et inteligenti dictus Dominus Vicarius et iudex precepit quatenus vadat et inquirat si poterit reperire seu aliquos culpabillem seu culpabilles furti antedicti referreret et denuncieret."

159 ASRe, Giudiziario, Atti e processi, February 22, 1382, fols. 427r-432v: “... et cum fuit ibi, cognovit quod erat corpus sive cadaver unius hominis quod videns turbatus mestus et timidus factus est et statit venit Albineam et hoc factum denunciavit consuli dicte terre, et diende consuli et ipsi castellano, qui castellanus misit de hominibus dicte terre ad custodiendo illa nocte dictum cadaver qui postea dictum cadaver portabunt ad ecclesiam."

16o ASRe, Giudiziario, Atti e processi, February 22, 1382, fols. 427r-432v.

161 On this investigation, see Vitiello, "Forensic evidence," 150-153. 
The interrogations of judges in the investigative stage tested witnesses' conclusions, but did not apparently seek to confirm them. In May of 1395, another body was discovered. This time, in the Villa de Veto, Caterina, daughter of Garofalus, was found dead in her home, strangled with a halter (capistri). ${ }^{162}$ Two weeks later, on May 30, Nicolaus de Castra Arboxa, acting at the commission of the judge of the Podestà of Reggio Emilia, interrogated a series of witnesses about Caterina's death. ${ }^{163}$

Once again, the witnesses were asked if they had seen the body, and if so, whether it was clear in what manner the victim had died. In this case, there was little doubt that a murder had been committed. Garofalus, the father of the victim — though at first he claimed to know nothing ${ }^{164}$ — shared his suspicion of a certain Antonius, because Antonius had often threatened Caterina, and often had beaten her. The judge then asked if Garofalus thought he knew how Caterina died, to which he responded confidently that the only possibility was that Antonius had killed her. ${ }^{165}$ Why, the judge inquired, was he so sure she was murdered? "He responded that when the said Caterina was carried to burial, he wished to see her nude, and he did not find her cut or wounded in any place; but she was bloodied between her flesh and skin [i.e. bruised], from the neck to the chest..."166 The strongest evidence against Antonius,

162 ASRe, Giudiziario, Atti e processi, May 30, 1395 and following days, unnumbered folios.

163 ASRe, Giudiziario, Atti e processi, May 30, 1395 and following days, unnumbered folios: “... Garofalus ... per sapientem virum Dominum Nicolaum de Castra Arboxa ad hoc commissarium iudicis Pomini potestatis Regii interrogatus...”

164 Massimo Vallerani noted the phenomenon of testes de nichio in accusatorial processes at Bologna. In the situations he examined, such witnesses were provided by the accuser, and they had to post a high surety of 300 pounds; in accusatorial trials of the thirteenth century, they appear to have some procedural necessity for the continuation of the process. Massimo Vallerani, "The Accusatory System in Action: Bologna between the Thirteenth and Fourteenth Centuries," in Medieval Public Justice, trans. Blanshei, 140-141. In scenarios perhaps more similar to inquisitorial trials of the later fourteenth century, these witnesses could also be a sign, as Stern observed, that witnesses were attached at the crime scene; see Stern, "Public Fame in the Fifteenth Century," 205. In Reggio, where "witnesses to nothing" still occur in both investigations and trials in the late fourteenth century, the claim to know nothing might also represent something more rhetorical on the part of the witness - an unwillingness to participate in the process, or perhaps to impugn themselves ("I cannot recall...").

165 ASRe, Giudiziario, Atti e processi, May 30, 1395 and following days, unnumbered folios: "Interrogatus si suspicatur qua mortua sit morte dicta Caterina. Respondit non suspicatur quod sit mortua alia morte nisi quod dictus eam necaverit."

166 ASRe, Giudiziario, Atti e processi, May 30, 1395 and following days, unnumbered folios: "Respondit quod quando dicta Caterina portabatur ad sepulcuram voluit eam videre 
however, came from his own mother, Dominica, who said that she had seen the body. She further told the judge that when she was rising early that morning, Antonius came to her and confessed, "I have killed Caterina." Distraught, Dominica cried, "Traitor! You have destroyed me!" As Antonius disappeared into the night, Dominica ran to the home of her neighbor, calling, "Godfather get up, because Antonius has killed Caterina! Get up, and go to her people and tell them about the death of Caterina!"167 Immediately he called two relatives to pursue Antonius, but they could not find him.

Dominica feared not the criminal judge, but the vendetta that Antonius's actions had brought to her house. She sought an intermediary to speak to the relatives of the murdered woman, presumably to minimize the danger of retaliation; her family was "fearful of the relatives of Caterina, who are powerful and numerous in that land of Veto."168 Antonius, his brother and even his aged father disappeared; his mother, sister, and young brother, apparently not suitable objects for retaliation, remained behind but all testified against Antonius in this inquest.

In this case, there was no need to pursue the issue of cause of death, about which all the witnesses appeared to agree. The issue that seemed to concern the judge the most was whether the other male members of the family who escaped with Antonius were co-conspirators. And so he interrogated the witnesses who suspected Antonius but not his relatives. "Domina Pedra, wife of Petrus de Veto, when asked the reason she suspected Antonius but not Canes or his other brothers, responded, 'He is thought to be the worst of all those living in that house'..."169 This sentiment was echoed by another witness, Bartolus, son of Andrea de Veto, who, when asked the same question, testified

nudam et non invenit eam percussam nec vulneratam in aliquo loco sed bene ipsam sanguinolentam inter carnem et pellem a gula usque ad pectus ipsius Caterine."

167 ASRe, Giudiziario, Atti e processi, May 30, 1395 and following days, unnumbered folios: “... et cum illamet nocte surgeret indilucullo diei dictus Antonius venit ad eam dicendo, 'Ego interfeci Caterinam.' Et ipsa respondit, 'Proditor! Tu consumpsisti me!' Et incontinenti exivit ex hostium dictus Antonius... et dicta testis remansit domi et exivit hostium et ivit ad domum cuiusdam vicini sui nomine Beltrame, 'Compater, surgatis! Quia Antonius interfecit Caterinam! Surgatis adcedatis ad aptinentes suos et dicatis eisdem de morte Caterine!' Et incontinenti suressit et vocavit duos aptinentes et incontinenti persecuti fuerunt dictum Antonium tamen reperire non potuerunt."

168 ASRe, Giudiziario, Atti e processi, May 30, 1395 and following days, unnumbered folios: "... interrogatus qua de causa recessit, si nulla suspicio erat contra eum, respondit quod timuit de aptinentibus dicte Caterine, quod in dicta terra veta sunt potentes et multos."

169 ASRe, Giudiziario, Atti e processi, May 30, 1395 and following days, unnumbered folios: "Interrogata quia suspicatur magis contra dictum Antonium quodam contra 
that "[Antonius] is considered the worst of all the brothers, and Canes [his brother] is considered to be a good young man."170 Flight, even before citation, was regarded if not as proof of guilt, then at least as a reasonable ground for suspicion. This is reflected in the case of Zanardus above, as the judge, attempting to determine whether Zanardus died through foul play, asked his witnesses whether anyone had recently disappeared from the territory. And when Caterina's father wished to implicate those other members of the family, the judge asked him if the other men had more likely fled out of fear of Caterina's relatives than because they were guilty. ${ }^{171}$

In both cases, the judge took the role of devil's advocate, asking the witnesses in Caterina's case if there was not some other possible explanation for Antonius's flight from the commune, while in Zanardus's case, where the locals were convinced that Zanardus's death was an accident, the judge asked pointed questions to determine if there was any possibility of foul play. In Caterina's case, where the locals were certain her death was murder, the judge wanted to know the exact grounds of their suspicions, and if there was not some other probable reason for the suspects' absence from the commune. In both investigations, the judge assumed the role of fact-finder.

Though the preliminary stages of investigation were generally left to his officials, sometimes the judge's preliminary investigative role was more substantial. On rare occasions, he visited crime scenes or directly observed the wounds of a crime victim. In the trial of Nicholaus filius Johannis de Flandria, who was accused of murdering a certain Antonius de Udeno near the palace of the Capitano, the judge himself viewed the body, and the trial was conducted ex officio. ${ }^{172}$ There is no evidence of a medical examination, implying that the detailed observations in the denunciation about the placement of the victim's

superscriptem Canem [Antonius's brother] et aptinentes suos respondit quia reputabatur peior omnibus aliis de domo sua...."

170 ASRe, Giudiziario, Atti e processi, May 30, 1395 and following days, unnumbered folios: “... [Antonius] reputabatur peior aliquorum fratrum et dictus Canes reputabatur bonus iuvenis."

171 ASRe, Giudiziario, Atti e processi, May 30, 1395 and following days, unnumbered folios: "Interrogatus si suspicatur quod praedicti excepto dicto Antonio fugam ariperuerint plus timore aptinentium dicte Caterine quam quod fuerint culpabilles dicti mallifici. Respondit, quod suspicatur quod magis affugerint timore aptinentium exceptio dicto Antonio et quodam Cane fratre dicti Antonii qui suspicatur quod de morte dicte Caterine aliquid sumpserit. Interrogtatus si suspicatur contra Ubertum fratrem predictorum Antonii et Canis. Respondit quod non quia est forte tredecim annorum vel circa."

172 See below, Chapter Two. 
wounds were made by the judge himself. ${ }^{173}$ However, this kind of direct invovlement by the judge is not often documented in these sources.

\section{Apprehension of Malefactors}

If the offices described above were the primary institutions of crime reporting and investigation, policing was largely a separate task. The Podestà traveled with his own berovarii, a sort of armed police charged with maintaining public order. ${ }^{174}$ Only the Podestà is described as having berovarii in the statutes ${ }^{175}$ but it is very likely that other officials, like the Knight of Justice or the captain of the military, did as well. Certainly in other cities like Florence, the latter half of the fourteenth century saw an increase in the number of officers employed to maintain law and order, and these men had contingents of berovarii. ${ }^{176}$ The familiares of the Podestà are found occasionally helping to investigate crime. ${ }^{177}$ The Knight of Justice of the commune was particularly charged with capturing and bringing to justice malefactores and banniti, "wherever they may be."178 These figures, however, seldom appear in the records.

Thefirstline of defense - againstcrimeandeverykind of socialdisturbancewas once again the people. While there was no compulsory military service for the inhabitants of Reggio Emilia, they were at various times required to take turns serving as guards for the city walls, piazzas, gates, towers, and castles. ${ }^{179}$

173 ASRe, Giudizario, Libri delle denunzie, December 6, 1392, vol. 14, fols. 159r-16ov.

174 Santoro, Gli offici del Comune di Milano, 227.

175 ASRe, Comune, Statuti del 1335/1371, fol. 18r, and ASRe, Comune, Statuti del 1392, fol. 144v.

${ }_{176}$ Andrea Zorzi, "The Judicial System in Florence," in Crime, Society and the law in Renaissance Italy, eds. Trevor Dean and Kate Lowe (Cambridge: Cambridge University Press, 1994): 49 .

177 ASRe, Giudiziario, Libri delle denunzie, November 10, 1389 .

178 ASRe, Comune, Statuti del 1335/1371, fol. 13v. The charge of the Knight of Justice to capture banniti may have overlapped uncomfortably with the later office of the Capitano del devieto.

179 While this requirement was briefly revoked at the beginning of Barnabò's reign, and three hundred men were employed specifically for this purpose, by November of 1372, the obligation was returned to the inhabitants of the land. This could be, as Grimaldi has suggested, because the expense was too great. See Grimaldi, La signoria di Barnabò Visconti, 117. It might also be the case that, in the first year of his rule before control of the city was firmly established, Barnabò was uncomfortable entrusting the position of defenders and guardians to the factionally-minded inhabitants of the town. 
Unsurprisingly, they also comprised the front lines in the struggle for public order, and the citizens of Reggio who witnessed crime were also obligated to attempt to seize and bring malefactors to justice. ${ }^{180}$ The statutes criminalized both actively aiding a criminal, and simply allowing one to escape. ${ }^{181}$ These were clearly jurisdictional concerns, as much as issues of public order. Failing to make an effort to apprehend a criminal by chasing him or seizing him could result in a harsh pecuniary penalty which could be applicable to an entire territory, given the circumstances. "If anyone commits any crime or robbery or plundering or arson or anything else similar... and the men of that land do not run and follow this malefactor, nor seize him, nor lead him into the hands of the Podestà and commune of Reggio, we institute and ordain that the aforesaid land or commune and the men living in it should be punished in the amount of 25 pounds R.L." Wards, orphans, widows, and the poor were exempt, and there was no penalty for failure- "if the men of the said settlements pursue him, although they do not catch him nor lead him to the control of the commune, they should incur no penalty."182

18 o ASRe, Comune, Statuti del 1335/1371, fol. 33r-v (see ASRe, Comune, Statuti del 1392, fol. 153-v): "Quod presentes ubi et quando fit homicidium vel malleficium et persone vicine ubi sit teneantur capere malefactorem, et post eum cridare et stremitam pulsare, et de pena contrafacientium."

181 See for example ASRe, Comune, Statuti del 1335/1371, fol. $29 v$ (cf. ASRe, Comune, Statuti del 1392, fol. 15or), " De pena illius qui tenuerit aliquem bampnitum comunis pro maleficio vel rebellem comunis in domo sua"; ASRe, Comune, Statuti del 1335/1371, fol. 33r-v (cf. ASRe, Comune, Statuti del 1392, fol. 153r-v), quoted above at n. 180; ASRe, Comune, Statuti del 1335/1371, fol. 34r (cf. ASRe, Comune, Statuti del 1392, fol. 153v), "De pena hominum terrarum districtus Regii et cuiuslibet comunis et terre non capientium et non prosequentium malefactorem in terra sua."

182 ASRe, Comune, Statuti del 1392, fol. 150v: "De penna terre et hominum non currentium ad capiendum mallefactorem comitente [sic] aliquod malleficium in terra sua ... si quis feceret malleficium aliquod vel robarium vel [de]predationem vel incendium vel quid aliud ... et homines illius terre non cucurrerint et eum malefactorem non fuerint prosecuti nec eum ceperint vel eum in forcia potestatis et comunis Regii eum duxerit, quod statuimus et ordinamus eos facere debere puniatur dicta terra seu comune illius et homines habitates in ea in vigintiquinque libras Rexanorum ad qua condempnatione non teneantur pupilli orfani et vidue et alie miserabilles persone, quod si homines dictarum villarum cucurrerint ad rumorem et suum posse ibi fecerint in capiendo mallefactore licet non ceperint nec in forciam comunis duxerint nullam penam incurrant." 
There were also strict rules preventing the harboring of fugitives. ${ }^{183}$ Harboring a criminal was considered a more serious crime than failing to aid in his apprehension, though this too was a crime with a significant monetary penalty, ${ }^{184}$ and the penalties for sheltering someone who had already been placed under ban were severe. ${ }^{185}$ The 1411 redaction of the statutes, made on the occasion of the Este acquisition of Reggio, simplified and presented consecutively the same material, but did not create any new categories of crime in non-reporting or non-seizure of criminals. ${ }^{186}$ But the 1411 redaction did change the structure of penalties, leaving them to the arbitrium of the Podestà without set limits, indicating the serious nature of the problem.

183 ASRe, Comune, Statuti del 1335/1371, fol. $29 v$ (cf. ASRe, Comune, Statuti del 1392, fol. 15or): "De pena illius qui tenuerit aliquem predatorem in domo sua. Item, si quis receperit vel retinuerit aliquem preditorem vel robatorem scienter in domo sua propria vel conducta vel alibi in civitate vel districtu Regii vel auxilium vel malum conscilium dedent si fuerit miles vel filius militis puniatur in quinquaginta libras Rexanorum. Si fuerit pedes puniatur in vigintiquinque libras Rexanorum. Si fuerit comunitas aliqua puniatur in centum libras Rexanorum nisi predictum robatorem vel predatorem duxerint potestati vel comuni Regii quo deducto non teneantur aliqui qui eum duxerint de que pena comunitatis non debeant aliquid solvere pupilli orphani vidue nec alie miserabiles persone."

184 ASRe, Comune, Statuti del 1392, fol. 15ov, quoted above at n. 226.

185 The statute is the same in both redactions: ASRe, Comune, Statuti del 1335/1371, fol. 29v: "Item, si aliquis bampnitum comunis Regii pro maleficio vel aliquem rebellem comunis Regii in domo sua propria vel conducta vel aliter gratis habita retinuerit scienter, si fuerit miles vel filius militis puniatur in vigintiquinque libras Rexanorum pro bampnito, pro rebelle in centum libras Rexanorum, nisi bampnitum vel rebellem duxerint in fortia potestis et comunis Regii infra octo dies postquam fuerit eis preceptum vel denunciatum per potestatem vel nuntium comunis Regii. Et quod universitas que tenuerit predictos contra predicta puniatur pro quolibet predictorum in quinquaginta libras Rexanorum de qua penna universitatis debeant solvere, id est, non pupili, orfani, vidue et alie miserabiles persone. Salvo eo, quod si illi de universitate propter potentiam bampniti vel rebellis non possent eum prohibere stare in dicta villa vel eum in fortiam comunis deducere quod dicta universitas excuseret a dicta pena si eum denuntiaverint potestati secrete vel pallam ita quod potestas ibi possit mittere officialles suos causa capiendi illum bampnitum vel rebellem."

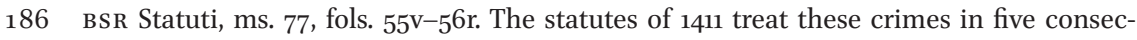
utive rubrics: "Quod fures et latrones possint capi et cetera"; "De pena impedientis ne malefactores consignentur"; "De pena auferentis aliquem malefactorem vel bannitum ex manibus Domini Potestatis"; "Quod universitas teneatur dare auxilium ad consignandum malefactors"; "De pena capientis aliquem malefactorem et ipsum non consignaverit vel manifestaverit." The 1411 statutes no longer established penalties for these crimes, but left their punishment to the arbitrium of the Podestà. This is in keeping with a wider move towards the allowance of judicial discretion; see Chapter Four. 
Such legislation delineated the boundaries of jurisdictional power. Perhaps indeed this was the primary emphasis of the framers of the statutes, because other means to encourage denunciation of crime were not used in Reggio. The city, unlike Siena and Florence, did not create systems of anonymous denunciation. In Siena, foreign police forces dominated the policing of the city, and secret accusers received a portion of the fine when their anonymous denunciations resulted in guilty verdicts. ${ }^{187}$ In Florence, tamburazioni, anonymous accusations left in boxes set out by the officials of the court, were part of a system of surveillance to gather information about criminal activity; ${ }^{188}$ a system which later would play a major role in certain types of prosecutions, especially those of homosexuality. ${ }^{189}$ At Reggio, there was no clear venue for anonymus denunciations. People who denounced crimes to the neighborhood captain or consul were not named as accusers but did appear as primary witnesses. When a crime occurred and the culprit was unknown, or when a death occurred under suspicious circumstances, or wounds were treated that appeared to result from violence-in all these cases, notifications were required to come to the criminal judge, who insisted upon it ne crimina remaneant impunita, but also, lest the right of the city to exert the merum imperium be challenged. Investigation, like prosecution, was a public statement of power.

This overview of communal government at Reggio Emilia and its criminal justice system shows the multiple layers of authority and jurisdiction in the city. The criminal court at Reggio and its officers functioned in a world of competing jurisdictions, and both open and covert expressions of power. The signore, the councils, the contado, conflicting political factions in the city, competing jurisdictions, bids for autonomy by the rural nobility, concessions of imperium and efforts to limit the same, personal vengeance and the vendetta - all these elements comprised the reality of medieval criminal justice, and the court constituted only one part. It is in this quite limited sphere that we must look at the development of inquisitorial procedure, and how it could be implemented, and sometimes manipulated.

187 William Bowsky, "The Medieval Commune and Internal Violence," 7.

188 Stern, Criminal Law System, 25-26. This system seldom resulted in accusations supported by enough evidence to bring the defendant to trial, however. Laura Ikins Stern, "Politics and Law in Renaissance Florence and Venice," The American Journal of Legal History 46 (2004): 218 .

189 Michael Rocke, Forbidden Friendships: Homosexuality and Male Culture in Renaissance Florence (Oxford: Oxford University Press, 1996), 49. 